\title{
RECENT THIRD POLE'S RAPID WARMING ACCOMPANIES CRYOSPHERIC MELT AND WATER CYCLE INTENSIFICATION AND INTERACTIONS BETWEEN MONSOON AND ENVIRONMENT Multidisciplinary Approach with Observations, Modeling, and Analysis
}

Tandong Yao, Yongkang Xue, Deliang Chen, fahu Chen, lonnie Thompson, Peng Cui, Toshio Koike, William K.-M. Lau, Dennis Lettenmaier, Volker Mosbrugger, Renhe Zhang, Baiqing Xu, Jeff Dozier, Thomas Gillespie, Yu Gu, Shichang Kang, Shilong Piao, Shiori Sugimoto, Kenichi Ueno, Lei Wang, Weicai Wang, Fan Zhang, Yongwel Sheng, Weidong Guo, Ailikun, Xiaoxin Yang, Yaoming Ma, Samuel S. P. Shen, Zhongbo Su, Fei Chen, Shunlin Liang, Yimin liu, Vijay P. Singh, Kun Yang,

DaqIng Yang, Xinguan Zhao, Yun QIan, Yu Zhang, and QIan LI

We present the latest development in multidisciplinary Third Pole research and associated recommendations regarding the unprecedented warming in the Third Pole's past 2,000 years.

$\mathrm{T}$ he Third Pole (TP) is the high-elevation area in Asia centered on the Tibetan Plateau and is home to around $1,000,000 \mathrm{~km}^{2}$ of glaciers, containing the largest volumes of ice outside the polar regions. The TP glaciers experience abrupt retreat under climate warming with westerly monsoon interaction (Yao et al. 2012b). More than 10 major rivers, including the Yangtze River, the Yellow River, and the Ganges River, originate from the TP, making it the "Water Tower of Asia." However, the Water Tower of Asia is now in danger due to rapid warming (Immerzeel et al. 2012). Although the TP ecosystems are greening as a whole under climate warming, there is a clear north-south contrast (M. G. Shen et al. 2015b).

Climate over the TP is complex. It is primarily influenced by the interaction between the Asian monsoon and midlatitude westerlies and is highly sensitive to climate change, which can exert major control on the atmospheric circulation at the local and continental scales. Meteorological records reveal that the warming rate on the TP is twice of that observed globally over the past five decades (Chen et al. 2015). Reconstructions of temperature changes on the TP in the past 2,000 years have provided a historical context for the recent warming and for various mechanism 
studies of climate change, as well as for their linkages with human activity to be tested and thereby enable more accurate projections of future scenarios.

This article presents a mini review of the state of TP multidisciplinary research and associated recommendations motivated from the "International Workshop on Land Surface Multi-Spheres Processes of Tibetan Plateau and their Environmental and Climate Effects Assessment" held in Xining, China, in August 2016. This TP workshop was organized by the Third Pole Environment (TPE), Institute of Tibetan Plateau Research, Chinese Academy of Sciences (ITPCAS), and the University of California, Los Angeles (UCLA), with more than 230 participants from China, the United States, Japan, Nepal, the Netherlands, India, and six other countries. The American Geophysical Union (AGU), the National Natural Science Foundation of China (NSFC), the U.S. National Science Foundation (NSF), the Chinese Academy of Sciences, and 14 other organizations/agencies/institutions sponsored the workshop. The workshop brings together professionals from around the world in different disciplines to present the most up-to-date TP research, exchange ideas, and research findings to broaden understanding and bridge existing knowledge gaps in the TP scientific research (Yao and Xue 2016). The workshop presentations and discussions covered all major TP research areas and provided a base for this overview article.
This paper covers the following TP research subjects: paleo-environment on the TP; major characteristics of changing TP climate and environment, associated intensified hydrological cycles, glacial change, and other physical processes over the TP; the TP surface processes and its local and remote influence on the Asian monsoon; the TP ecosystem dynamics and its association with climate change and anthropogenic impact; the TP aerosols' characteristics and their influence on the atmosphere and environment; and increased hazard risks on the TP.

\section{TP TEMPERATURE CHANGE IN THE PAST} 2,000 YEARS. The stable oxygen isotope $\left(\delta^{18} \mathrm{O}\right)$ records in Tibetan ice cores are taken as proxies to represent the temperature on a long-term time scale (Thompson et al. 1997; X. Yang et al. 2014; Yao et al. 1996a,b, 1999, 2007). The $\delta^{18} \mathrm{O}$ and temperature relations have been studied over the globe and a linear relation between these two has been established. For instance, the slope of linear regression $\left(0.69 \%{ }^{\circ} \mathrm{C}^{-1}\right)$ was spatially derived for mid- and high-northernlatitude coastal stations (Dansgaard 1964), and the slope $\left(0.67 \%{ }^{\circ} \mathrm{C}^{-1}\right)$ was obtained for southern and western Greenland (Johnsen et al. 1989). Based on a quasi-decadal time series of $\delta^{18} \mathrm{O}$ in precipitation at Delingha on the northern TP (Yao et al. 1996b), a temporal slope of $0.66 \%{ }^{\circ} \mathrm{C}^{-1}$ was obtained (Tian et al.
AfFiliations: Yao, Fa. Chen, Xu, L. Wang, W. Wang, F. Zhang, AILIKUN, $X$. YANG, MA, AND K. YANG-Institute of Tibetan Plateau Research, Chinese Academy of Sciences, Beijing, China; XUE, LetTenmaier, Gillespie, Gu, AND SHenG-University of California, Los Angeles, Los Angeles, California; D. CHEN-Department of Earth Sciences, University of Gothenburg, Gothenburg, Sweden; THOMPSON-Byrd Polar and Climate Research Center, and School of Earth Sciences, The Ohio State University, Columbus, Ohio; CulInstitute of Mountain Hazards and Environment, Chinese Academy of Sciences, Chengdu, China; KoIKE-International Centre for Water Hazard and Risk Management, Tsukuba, Japan; LAU-Earth System Science Interdisciplinary Center, University of Maryland, College Park, College Park, Maryland; Mosbrugger-Senckenberg Research Center for Nature, Frankfurt, Germany; R. ZHANG—Department of Atmospheric and Oceanic Sciences, and Institute of Atmospheric Sciences, Fudan University, Shanghai, China; DozIeR-Bren School of Environmental Science and Management, University of California, Santa Barbara, Santa Barbara, California; S. KANG-State Key Laboratory of Cryospheric Science, Northwest Institute of EcoEnvironment and Resources, Chinese Academy of Sciences, Lanzhou, China; PIAO-College of Urban and Environmental Science, Peking University, Beijing, China; Sugımoto-Japan Agency for MarineEarth Science and Technology, Yokohama, Japan; UENO-Faculty of Life and Environmental Sciences, University of Tsukuba, Tsukuba, Japan; Guo-School of Atmospheric Sciences, Nanjing University,
Jiangsu, China; SHEN-Department of Mathematics and Statistics, San Diego State University, San Diego, California; Su-Faculty of Geo-Information and Earth Observation, University of Twente, Enschede, Netherlands; FE. CHEN—NCAR/RAL, Boulder, Colorado; LIANG-Department of Geographical Sciences, University of Maryland, College Park, College Park, Maryland; LIU—LASG, Institute of Atmospheric Physics, Chinese Academy of Sciences, Beijing, China; SINGH-Department of Biological and Agricultural Engineering, and Zachry Department of Civil Engineering, Texas A\&M University, College Station, Texas; D. YANG-Environment and Climate Change Canada, Saskatoon, Saskatchewan, Canada; ZHAO-Chengdu Institute of Biology, Chinese Academy of Sciences, Chengdu, China; QIAN-Pacific Northwest National Laboratory, Richland, Washington; Y. ZHANG - School of Atmospheric Sciences, Chengdu University of Information Technology, Chengdu, China; LI-Institute of Atmospheric Physics, Chinese Academy of Sciences, Beijing, China CORRESPONDING AUTHOR: Yongkang Xue, yxue@geog.ucla.edu

The abstract for this article can be found in this issue, following the table of contents.

DOI:10.II75/BAMS-D-17-0057.I

In final form 30 August 2018

(C)2019 American Meteorological Society

For information regarding reuse of this content and general copyright

information, consult the AMS Copyright Policy. 
2003), which is very close to the ones derived in previous studies over other parts of the world. The discussion of temperature changes in the past 2,000 years in this section is mainly based on four $\delta^{18} \mathrm{O}$ in ice cores recovered from the $\mathrm{TP}$, including the Guliya ice core in the northwest TP $\left(35.3^{\circ} \mathrm{N}, 81.5^{\circ} \mathrm{E}\right)$, the Dunde ice core from the northeast TP $\left(38.1^{\circ} \mathrm{N}, 96.4^{\circ} \mathrm{E}\right)$, the Puruogangri ice core in the central $\mathrm{TP}\left(33.9^{\circ} \mathrm{N}, 89.1^{\circ} \mathrm{E}\right)$, and the Dasuopu ice core in the southern TP $\left(28.4^{\circ} \mathrm{N}\right.$, $\left.85.7^{\circ} \mathrm{E}\right)$. The ice core collection started as early as the 1980s and still continues (e.g., Yao and Thompson 1992; Thompson et al. 2006). These four ice cores are the only ones that cover at least the past 2,000 years on the TP so far.

Over the past 2,000 years, $\delta^{18} \mathrm{O}$ in the Guliya ice core record has increased (Fig. 1a), although with fluctuations. The record can be divided into seven cold periods and eight warm periods, and toward the present the temperature shows greater warmth in the warm periods and less cold in the cold ones, with the warmest period occurring in the twentieth century. The Little Ice Age (LIA) in the TP was represented by three cold events in the sixteenth, seventeenth, and nineteenth centuries. However, the LIA is not the coldest period in the past 2,000 years (Yao et al. 1996a,b).

The $\delta^{18} \mathrm{O}$ record for the Dunde ice core (Fig. 1a) shows overall decreasing temperature trends with fluctuation starting in the fifth century and culminating to the coldest climate in the tenth century, followed by a warming to the relative warmth of the thirteenth century. The LIA started in AD 1400 and contained three cold periods in the fifteenth, seventeenth, and nineteenth centuries (Yao and Thompson 1992), culminating in the warm twentieth century.
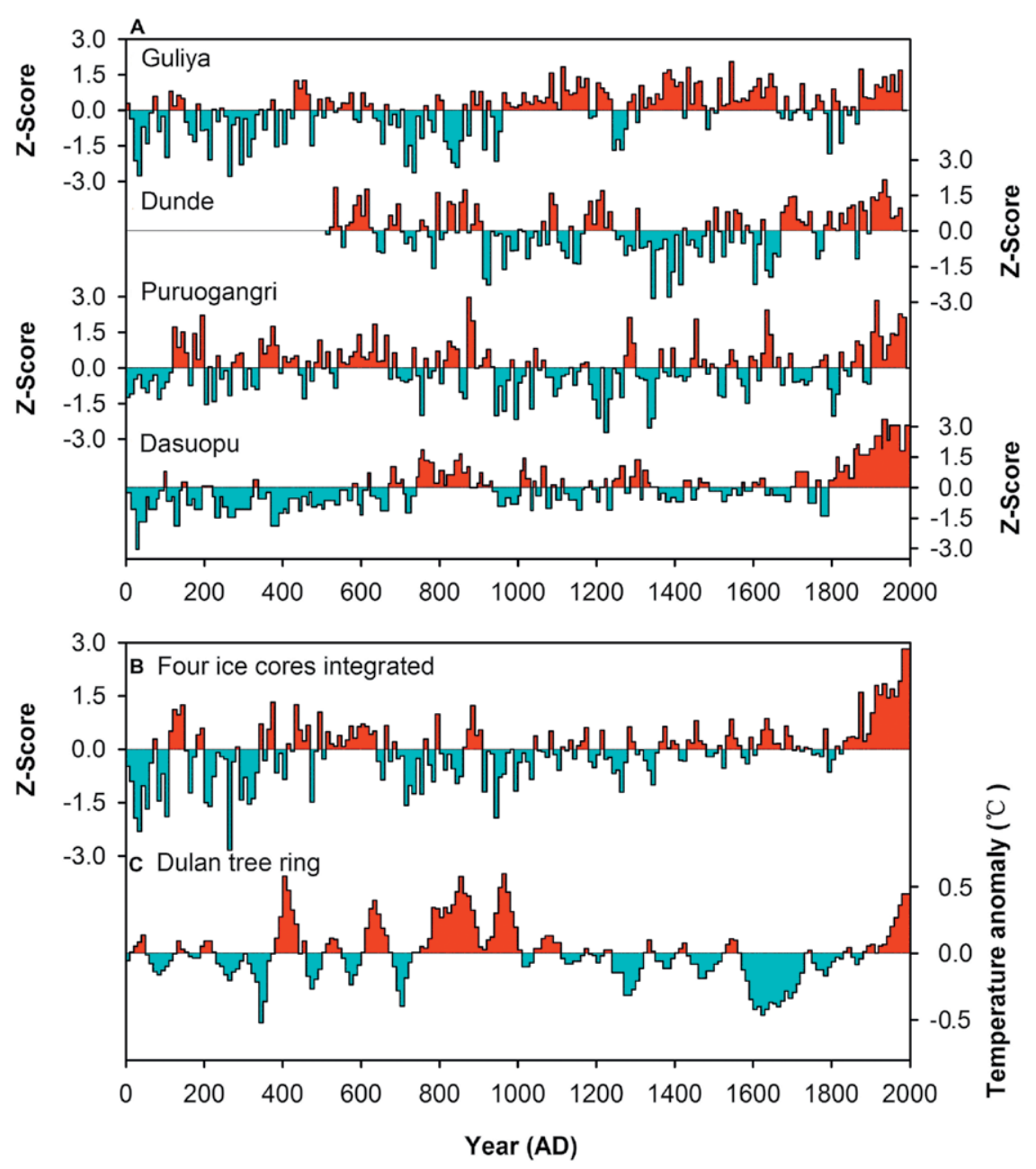

FIG. I. Ice core and tree-ring climate records in the TP (red = warm climate; blue $=$ cold climate). (a) 10 -yr averages of $\delta^{18} \mathrm{O}$ in the past 2,000 years recorded the Guliya, Dunde, Puruogangri, and Dasuopu ice cores. (b) Temperature reconstructed from tree rings. The $z$ score in the figure refers to the normalized anomalies, which consider both mean and standard deviation

In the Puruogangri ice core, the $\delta^{18} \mathrm{O}$ record (Fig. 1a) illustrates a temperature transition from frequent and intense cooling to obvious warming around AD 1000. The twelfth to thirteenth centuries were a period of minor warming, and the nineteenth century was cold. This record indicates little about the Medieval Warm Period (MWP), and the LIA is not clearly expressed in this ice core record, but the twentieth century warming is significant (Thompson et al. 2006).

Temperature anomalies recorded by $\delta^{18} \mathrm{O}$ in the Dasuopu ice core (Fig. 1a) show cool periods between AD 0 and 700 and between AD 1000 and 1840 , although, like Puruogangri, the MWP is poorly expressed. Temperatures dropped to the lowest levels at the beginning of the nineteenth century, marking 
the LIA in this region, and as in the other ice core records the warming trend was very clear during the twentieth century (Yao et al. 2002).

After examining the $\delta^{18} \mathrm{O}$ records in the four ice cores, a comprehensive temperature proxy curve can be delineated (Fig. 1b) that shows an overall warming trend during the past 2,000 years. The climate remained stable with little fluctuation until AD 1600, followed by three significant cold periods in the seventeenth, eighteenth, and late nineteenth centuries. Rapid warming began in the 1960 s, culminating in the highest levels of the past two millennia in the last 30 years.

Tree-ring records are also regarded as temperature proxies. The reconstruction of tree-ring width at the Dulan upper forest limit on the east TP covers the past 2,000 years and is compared with ice core records (Y. Liu et al. 2009). The annually resolved time series of temperature anomalies during the past 2,000 years (Fig. 1c) show a slow temperature decrease from the early first century to AD 350 characterized by strong interannual and decadal variability. Temperature anomalies exhibit drastic fluctuations afterward. However, because of limited sample density, substantial changes between the years AD 784 and 989 cannot be confirmed. Several cold periods occurred between the sixteenth and eighteenth centuries, representing the LIA in this region. Just as in the ice core records, the late-twentieth-century warming trend is significant. Overall, the records of temperature changes retrieved from tree rings are consistent with those from ice cores over the northeast TP.

Records of temperature variations from ice core and tree-ring records are consistent over the past 2,000 years. From the third to the fifth century, the temperature was relatively low and was followed by moderate warming from the fifth to the mid-twelfth century. Warming continued from the mid-twelfth century to the late fourteenth century and was followed by the LIA cold climate from the fifteenth to the late nineteenth century. In both types of proxy records, the accelerating warming (Fig. 1) since the beginning of the twentieth century on the TP is unprecedented in the last 2,000 years (Yao et al. 2007; Thompson 2017; Thompson et al. 2018).

It should be pointed out that the TP proxy data are not only useful for paleoclimate analyses, but also have the potential to provide valuable information for the paleo models' cross validation over the TP region; the designs of such paleo model intercomparison experiments have been reported recently (e.g., Kageyama et al. 2018; Jungclaus et al. 2017).

\section{RECENT RAPID ATMOSPHERIC WARM-} ING ON THE TP. The climate on the TP is characterized by low air temperatures, high diurnal temperature range (DTR), and low seasonal temperature variations (Xie and Zhu 2013). The annual mean temperature across the TP is generally below $0^{\circ} \mathrm{C}$ and decreases from east to west (Frauenfeld et al. 2005). The TP has undergone significant warming during the recent decades (Liu and Chen 2000; Zhou and Zhang 2005; Wang et al. 2008; Zhang and Zhou 2009; Guo and Wang 2012; Chen et al. 2013; Zhu et al. 2013; Song et al. 2014; Cai et al. 2017). The warming in this region started in the early 1950s, much earlier than in the Northern Hemisphere $(\mathrm{NH})$, which started in the mid-1970s (Liu and Chen 2000; Niu et al. 2004). From 1955 to 1996 the warming rate was $0.16^{\circ} \mathrm{C}$ decade $^{-1}$, substantially higher than that of the $\mathrm{NH}\left(0.054 \mathrm{~K} \mathrm{decade}^{-1}\right)$ and of the northern midlatitudes during the same period (Liu and Chen 2000; Oku et al. 2006; Duan and Xiao 2015). A sudden jump in the warming occurred during the mid-1980s (Niu et al. 2004). The most dramatic temperature increase occurred during the 1990s (Gao et al. 2015), with a rate of $0.25^{\circ} \mathrm{C} \mathrm{decade}^{-1}$ from 1998 to 2013 (Duan and Xiao 2015), which is in contrast to the cooling trend in the rest of China. Figure 2 shows the variations in the annual mean temperature record, averaged over 91 stations on the TP, during the period from 1970 to 2014, which is compared with that averaged using the Climatic Research Unit gridded data (Jones et al. 2012) for the continent in the NH high-latitudinal (to the north of $60^{\circ} \mathrm{N}$ ) region. During the period from 1970 to 2014 , the warming rate of the annual mean temperature based on the average of 91 stations on the TP was $0.35^{\circ} \mathrm{C}$ decade $^{-1}$, slightly lower than the warming rate $\left(0.48^{\circ} \mathrm{C}\right.$ decade $\left.^{-1}\right)$ over the continent in the $\mathrm{NH}$ high-latitudinal region using the Climatic Research Unit (CRU) gridded data. The published record showed that the Antarctic decadal temperature trend during $1957-2006$ was $0.12^{\circ} \mathrm{C}$ decade $^{-1}$ (Steig et al. 2009). The data indicate the TP had a significantly stronger warming compared with those over the $\mathrm{NH}$ and northern midlatitude. The TP warming rate was slightly less than the one in the NH high-latitude area, but it was higher than the published Antarctic records (Steig et al. 2009; Bromwich et al. 2013). The strongest warming occurred in the winter months (Du et al. 2004; Liu and Chen 2000; Chen et al. 2006), about twice as much as the annual mean (Liu and Chen 2000). The magnitude of climate warming increases from south to north; the most significant warming was found in the northern part of the TP (e.g., Yang et al. 2011; Chen et al. 2013; You et al. 2016). 
Similar to mean air temperature, both minimum and maximum temperatures $\left(T_{\min }\right.$ and $T_{\max }$, respectively) exhibited significant warming trends $\left(0.45^{\circ}\right.$ and $0.26^{\circ} \mathrm{C}$ decade $^{-1}$, respectively) from 1961 to 2005 (Duan et al. 2006; Duan and Wu 2006; You et al. 2008). In particular, during the period 1970-2014, $T_{\text {min }}$ and $T_{\max }$ reached $0.42^{\circ}$ and $0.34^{\circ} \mathrm{Cdecade}^{-1}$, only slightly less than the warming rates of $T_{\text {min }}\left(0.55^{\circ} \mathrm{C}\right.$ decade $\left.^{-1}\right)$ and $T_{\text {max }}\left(0.43^{\circ} \mathrm{C}\right.$ decade $\left.^{-1}\right)$ for the $\mathrm{NH}$ high latitudes, respectively (Fig. 2). Due to greater warming in $T_{\min }$ than in $T_{\max }$, the DTR decreased noticeably: $-0.19^{\circ} \mathrm{C}$ decade $^{-1}$ during 1979-2012 (Yang and Ren 2017) and $-0.08^{\circ} \mathrm{C}$ decade $^{-1}$ during 1970-2014 (Fig. 2), respectively. Studies found that the changes in radiative processes were mainly responsible for the decreased DTR (e.g., Yang and Ren 2017). The increased low cloud cover tended to induce radiative cooling during daytime and warming during the night (Yang and Ren 2017; Duan and Xiao 2015).

There is growing evidence of elevationdependent warming (EDW; Pepin et al. 2015; Thompson et al. 2018), or amplified warming rate with elevation (X. P. Li et al. 2017), over and around the TP (Fig. 2).

This phenomenon is especially pronounced during winter and fall, as indicated by in situ observation data from stations below 5,000 m above mean sea level (MSL; Yan and Liu 2014). The Moderate Resolution Imaging Spectroradiometer (MODIS) data suggest that EDW

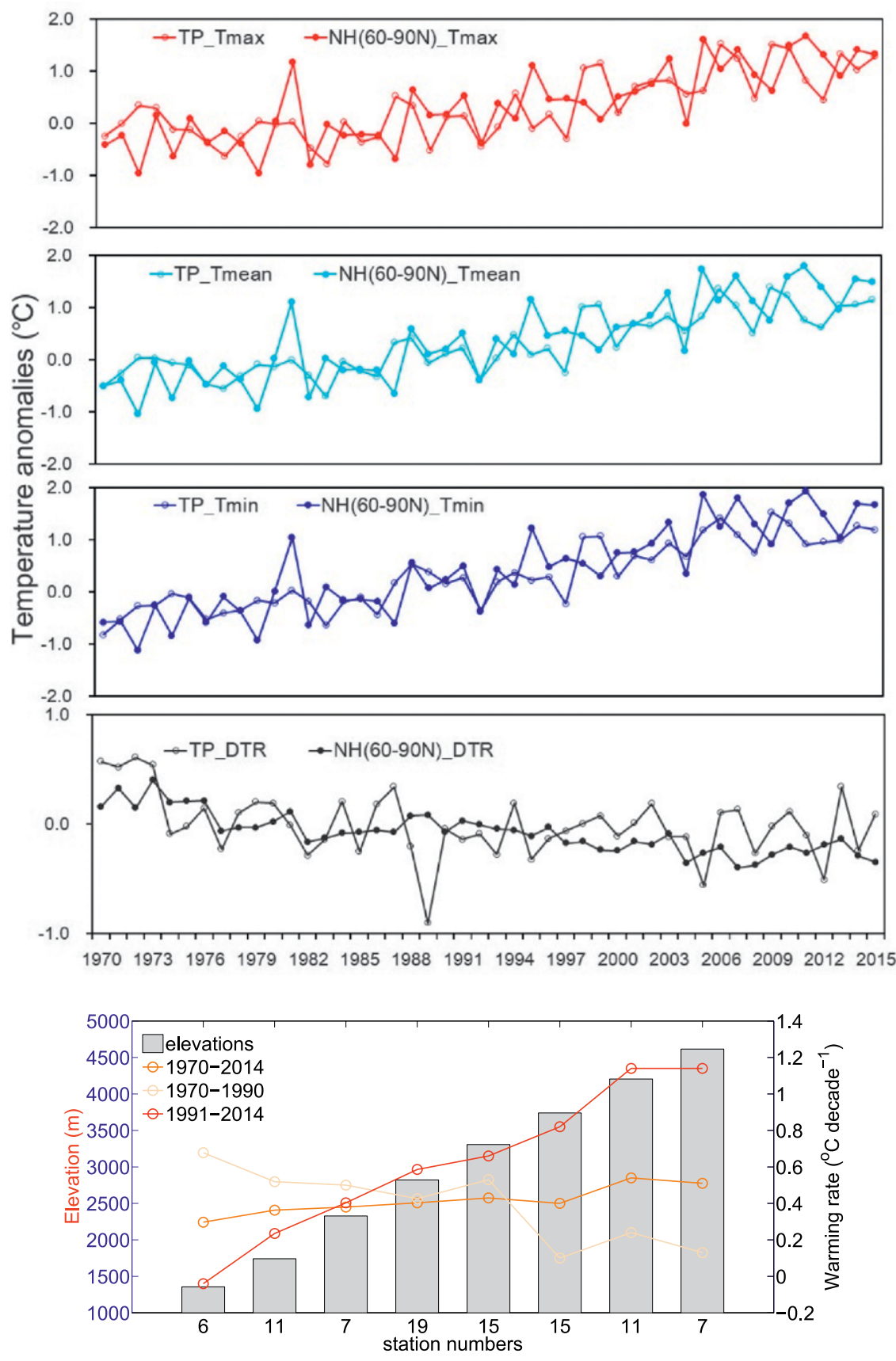

FIG. 2. (top) Time series of annual mean maximum, mean, and minimum air temperature anomalies, and diurnal temperature range over the TP region and $\mathrm{NH}$ high-latitude $\left(60^{\circ}-90^{\circ} \mathrm{N}\right)$ region, respectively, and (bottom) elevation dependence of winter mean air temperature over the TP during the period 1970-20I4. The TP temperature data are from $9 \mathrm{I}$ in situ stations derived by China Meteorological Administration, while those for the NH high latitudes are derived from CRU 4.0. The anomaly is calculated based on the 1971-2000 climatology.

may not occur above 5,000 m MSL (Qin et al. 2009). Mean minimum temperatures also show that EDW occurs on an annual basis (Yan and Liu 2014; X. D. Liu et al. 2009). Such tendencies have manifested mainly since the 1990s (Fig. 2) and may continue in 
the future, especially during the winter and spring seasons (X. D. Liu et al. 2009).

As a consequence of the greenhouse effect, the TP is warming faster than the global average. Studies also suggest that increased absorbed energy through the snow-albedo feedback (Liu and Chen 2000) and cloud-radiation interactions (Duan and Xiao 2015) may also contribute to this rapid warming over the TP. Decreased snow cover increases the absorption of solar shortwave radiation, which then enhances atmospheric warming (Rangwala et al. 2010). Meanwhile, less cloud cover results in more downward solar radiation, which ultimately causes surface warming (Zhang et al. 2008; Kuang and Jiao 2016). In addition, changes in surface water vapors, atmospheric circulation, and land uses are all likely contributors to the warming, especially for winter warming on the TP (Cui and Graf 2009; Rangwala et al. 2009). Moreover, effects of snow-albedo feedbacks and solar radiations are also responsible for the warming, especially the EDW, in the TP (Zhang et al. 2003; Chen et al. 2003). The current snow line is expected to retreat to higher elevations under the overall climate warming. The surface absorbs more incoming solar radiation as the snow line retreats upslope, which then causes enhanced warming at that elevation. The warming leads to more snow melting and snow-line ascension, forming a positive feedback.

The accelerated climate warming on the TP has caused significant glacier retreat, snowmelt, permafrost degradation, vegetation change, and increased climate aridity, which will be discussed in the next section and in the "Impact on ecosystem" section (Cheng and Wu 2007; Piao et al. 2010; Yao et al. 2012a; Guo and Wang 2013; Immerzeel et al. 2010; K. Yang et al. 2014; Gao et al. 2015; Xu and Liu 2007). Despite the significant progress in understanding the warming TP environment, scientists have identified several issues that need further investigation. Current evidence for rapid warming and significant EDW phenomenon generally come from in situ data below 5,000 m MSL. However, how the air temperatures did, and will, change above 5,000 m MSL is still unknown due to lack of in situ observations, as these regions are largely covered by glaciers and snow. Furthermore, model projections have suggested more obvious warming on the TP in the twenty-first century compared with the rest of China (Xu et al. 2003). Under the Special Report on Emissions Scenarios (SRES) A1B scenario, a $4^{\circ} \mathrm{C}$ warming is likely to occur over the TP within the next 100 years (Meehl et al. 2007). The mechanisms driving the rise of future temperature have not been comprehensively investigated. It is imperative to investigate both how air temperatures change in regions of higher elevation and the driving mechanisms for future warming. The warming and its altitudinal dependence have great implications for TP water resources and environmental changes.

\section{RECENT INTENSIVE CRYOSPHERIC MELT AND HYDROSPHERIC RESPONSES. Climate} warming brought remarkable changes to the cryosphere on the TP, including glacier retreat and variations in snow amount and cover, as well as increase in temperature, degradation of permafrost, and thickening of the active layer (Kang et al. 2010a ; Bibi et al. 2018). Yao et al. (2012b) conducted a comprehensive and systematic assessment of the glacier status on the TP and its surrounding regions. They investigated the retreat rate of 82 glaciers, the area reduction of 7,090 , and mass balance changes in 15 glaciers. They concluded that the glaciers were experiencing extraordinary shrinkage, as shown by the reduction in glacial length and area, and negative mass balance. The most intensive shrinkage occurred in the Himalayas (excluding the Karakorum). The shrinkage was not homogeneous across the TP: it generally decreased from the Himalayas to the continental interior and was least pronounced in the eastern Pamir (Fig. 3a).

Snow-covered days and snow depth also show great changes, though with regional and periodical differences. Both numbers decreased in the north and northwest regions, while they increased in the southwest edge and the southeast part of the TP from 2000 to 2014 (Huang et al. 2016). Overall, in situ observations and multisensor satellite data (Qin et al. 2006) show a small increasing trend in snow cover over the TP between 1951 and 1997, and a slight decreasing trend was identified between 1997 and 2012, mostly through the use of satellite images (S. S. Shen et al. 2015). Newer methods are expected to be able to directly measure the snow depth (Dozier et al. 2016). Using the observed temperature and precipitation with other meteorological forcing and a land surface model, the increase in the area-mean active layer thickness by $0.15 \mathrm{~m} \mathrm{decade}^{-1}$ in 1981-2010 was simulated (Guo and Wang 2013). Figure 3b shows a nearly homogeneous increase in the active layer thickness over TP. Long-term soil temperature measurements indicated that the lower altitudinal limit of permafrost moved up by $25 \mathrm{~m}$ in the north of the TP during the 1980s, 1990s, and 2000s and between 50 and $80 \mathrm{~m}$ in the south of the TP during the 1990s and 2000s (Cheng and Wu 2007). The permafrost area and the soil freeze depth have generally decreased in the TP during the 1980s, 1990s, 2000s, and 2010s, as 
(a) Glacier

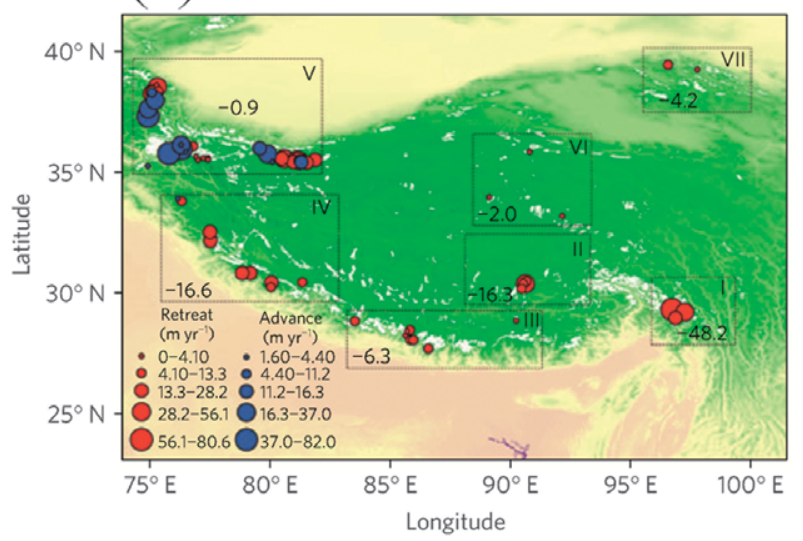

(c) Lakes

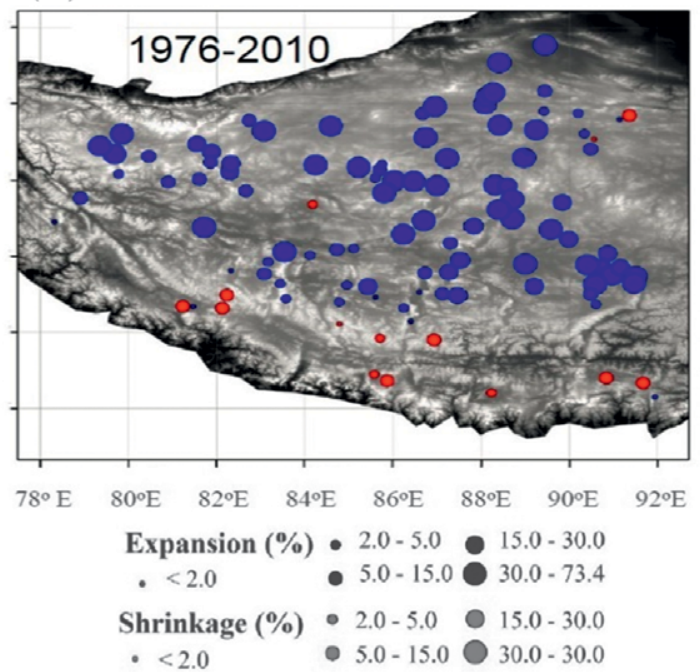

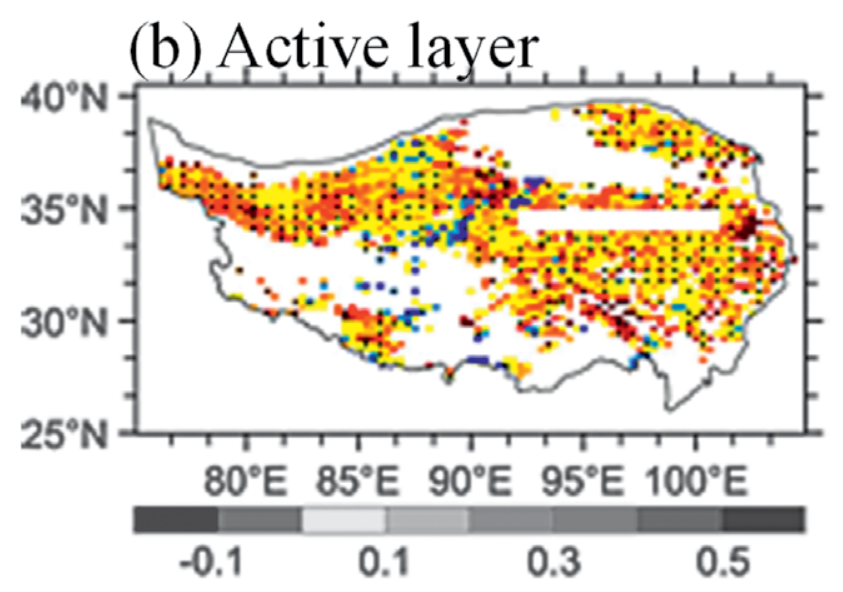

(d) Runoff

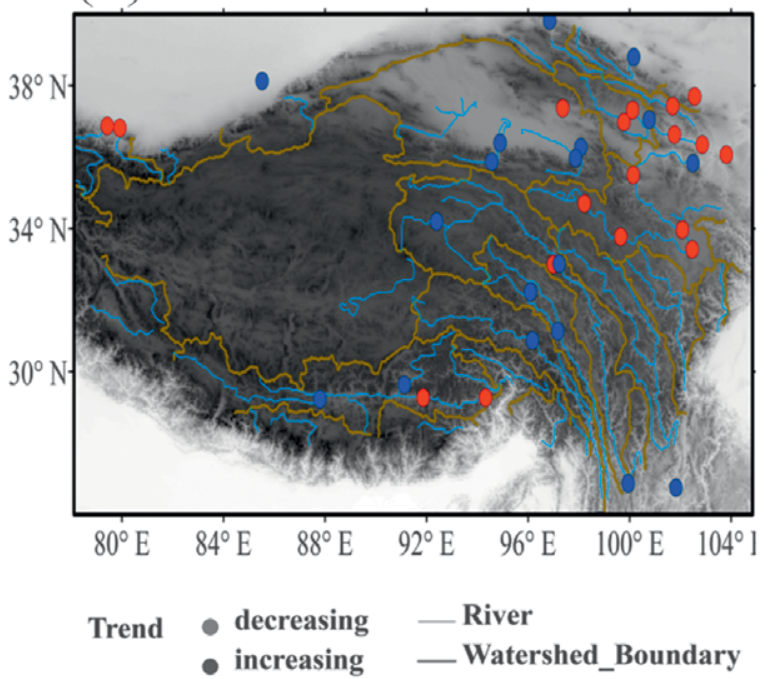

Fig. 3. (a) Observed changes in glacier ( $\mathrm{m} \mathrm{yr}^{-1}$; from Yao et al. 2012b), (b) simulated changes in active layer thickness during 198I-2010 (m decade ${ }^{-1}$; from Guo and Wang 2013), (c) observed changes in lake areas during 1976-2010 (from Lei et al. 2014), and (d) runoff change based on hydrological station data (modified from Cuo et al. 2014).

supported by both observational data and numerical simulation results (Guo and Wang 2013; Peng et al. 2017). Another study showed the thickness of seasonally frozen ground in the TP decreased by $0.05-0.22$ $\mathrm{m}$ from 1967 to 1997 , and the permafrost temperature increased by $0.2^{\circ}-0.5^{\circ} \mathrm{C}$ from the $1970 \mathrm{~s}$ to the $1990 \mathrm{~s}$ over most of the TP (Zhao et al. 2004).

Inland lakes over the TP have also responded to the rapid climate warming. There is a contrast in lake dynamics between the TP interior and the Himalayas region. Since the middle of the 1990s, major lakes in the central TP have expanded significantly both in area and depth, whereas many lakes along the marginal region of the south and east TP have shrunk (Fig. 3c; Lei et al. 2014; K. Yang et al. 2014; Sheng and Li 2011; Sheng 2014). Increased precipitation may mainly be responsible for lake expansion in the central TP along with a contribution due to enhanced meltwater from cryosphere (Lei et al. 2014; K. Yang et al. 2014). On the other hand, reduced precipitation caused lake shrinkage in the Himalayas (Lei et al. 2014). The Qinghai Lake, the largest lake in China, shows dramatic lakelevel fluctuation: it experienced a dramatic 3-m reduction of the lake level during 1961-2000, and then an increase by $1 \mathrm{~m}$ since. It seems that the climate variability and change, as well as anthropogenic influence, all played a role in the fluctuation (X. Li and D. Yang 2018, unpublished manuscript).

Furthermore, the river discharge has also changed under the climate warming. Through the multiple influences of glacier, permafrost, lake, snow, and climate, the runoff at hydrological stations show 
different characteristics: some are increasing and others are decreasing (Fig. 3d). The combined effects of spatiotemporal variations of precipitation, evaporation, and meltwater led to decreased discharge in the southern and eastern TP and a slight increase in the central TP since the beginning of the 1980s (Yang et al. 2011; K. Yang et al. 2014). At the basin scale, streamflow was dominated by precipitation in the northern, eastern, and southeastern basins, while meltwater or groundwater also contributed to streamflow in the central and western basins (Cuo et al. 2014). In large part, streamflow and lake variations are the products of the multispherical interactions in the TP Earth system and are directly affected by climate warming (K. Yang et al. 2014; Yao et al. 2015).

Accurate monitoring of cryospheric and hydrospheric processes are essential for understanding the changing multispherical interactions on the TP and for predicting their regional responses to climate warming. The recent studies highlighted the importance of in situ observations, which are required to support the application of relevant research methods (e.g., remote sensing, hydrological modeling, and other physically based methods). During the 2000s, in addition to the glacial measurements over the TP (Yao et al. 2012b), some in situ observations with more physical variables have been established, such as soil moisture and temperature monitoring networks in Naqu and Pali (Chen et al. 2017), inflow and evaporation measurements at typical lakes (Zhou et al. 2013), and observations of snow and glacier melt runoff in glacier-fed basins (Zhang et al. 2016). However, there remain large ungauged areas over the western $\mathrm{TP}$, where the climate and environmental conditions are quite harsh. We suggest that numerical modeling tools with coupled cryospheric and hydrospheric processes along with multispherical observational data (e.g., Wang et al. 2017) should be developed in order to better physically and comprehensively understand the mechanism of lake change and runoff variations over the TP.

\section{INTERACTIONS BETWEEN TP SURFACE PROCESSES AND MONSOONS. One of} the most imperative topics for the TP atmospheric research under changing climate and environment conditions are atmospheric energy and water circulations associated with land-atmosphere interactions over the TP and its surrounding regions. The TP has been identified as a region with the strongest land-atmosphere interactions in the midlatitude areas (Xue et al. 2010, 2017). This section focuses on the land-atmosphere interaction under the present climate with relatively short time scales (subseasonal to interannual).

The TP has a unique planetary boundary layer (PBL). The PBL over the TP is about $9 \mathrm{~km} \mathrm{MSL}$, much higher than many other regions. Results from reanalyses and modeling studies have indicated that weak atmospheric stability and the resultant deep PBLs were associated with higher upper-level potential vorticity values, which corresponded to a more southerly jet position and higher wind speeds (X. L. Chen et al. 2016). The penetrating convection and deep PBL south of the plateau are quite important in bringing up water vapor and aerosols into the tropopause/lower stratosphere, which may change the atmospheric heat balance across Asia.

With the unique geographic and atmospheric structure, the TP surface processes play an important role in regional climate. The basic atmospheric and land thermal and dynamic characteristics over the $\mathrm{TP}$, as well as their relationships with the Asian monsoon based on recently available datasets, are an important subject in TP research (e.g., Li et al. 2014a; Lin et al. 2016; Ma and Ma 2016; Ge et al. 2017). Radiosonde data and a land data assimilation system coupled with a mesoscale model show that the vertical profile of temperature in the premonsoon season as a whole was warming below $200 \mathrm{hPa}$ and cooling above $200 \mathrm{hPa}$. However, there were also relative warming and cooling subperiods alternately during this premonsoon period showing opposite temperature profiles. Furthermore, the troposphere over the TP in the subwarming periods was divided into three vertical layers in terms of the major heating processes: sensible heat transport below $450 \mathrm{hPa}$, latent heat from 450 to $250 \mathrm{hPa}$, and horizontal advection above $250 \mathrm{hPa}$ originating in the southwest of the plateau. The cooling subperiods also exhibit similar vertical structures of each heating component, but net heating was reversed because of the influence of synoptic-scale disturbances through horizontal advection (Tamura and Koike 2010; Seto et al. 2013).

The mesoscale convective systems (MCSs) over the TP are closely related with heavy rainfall (Li et al. 2011) and rainfall diurnal variation (Li et al. 2014b), and they affect the MCSs in the downstream region (L. Li et al. 2017). The relationship between MCSs and soil moisture/precipitation has been investigated using different satellite and reanalysis products (Fig. 4; Sugimoto and Ueno 2010; Ueno et al. 2016; Zeng et al. 2016). These studies found that the occurrences of MCSs in the eastern and central-southern TP occurred with and without precipitation, respectively, indicating different vertical structure of MCSs and 
land surface heating condition in these two regions. On the interannual scale, a weak Indian monsoon accompanied drier and wetter soil moisture over the central-southern TP and eastern and western TP, respectively, with more precipitation in the eastern TP. The main driver was due to the enhancement of west-east soil moisture contrasts as discussed in Ueno et al. (2016).

Various studies have explored the mechanisms through which Tibetan land processes interact with the atmosphere. Based on a general circulation model (GCM) study with and without sensible or latent heat as well as associated diagnostic analysis, it was found that sensible heating from the land surface and latent heating from cloud convection in the entire atmospheric column during the summer could induce a prominent center of minimum absolute potential vorticity and anomalous potential vorticity forcing near the tropopause within the westerly flow. These effects enhanced the meridional circulation of the Asian summer monsoon and influenced circulation in the Northern Hemisphere (Wu et al. 2016; Y. M.
Liu et al. 2013). Moreover, analysis of the results from the regional climate model (RCM) experiments with and without a diurnal cycle of solar radiation show that a diurnal variation in solar radiation increases the sensible heat flux at the ground and enhances the thermal low near the surface and the summertime anticyclonic circulation in the upper troposphere over the TP. This is because the daytime solar flux was much greater than the nighttime cooling over TP, which also enhanced the South Asian and East Asian summer precipitation (Hong et al. 2012). Furthermore, the TP's topographic effects were also discussed (Ma et al. 2014; Song et al. 2010).

Application of the TP land condition for the subseasonal to seasonal (S2S) prediction, especially the extreme events, is an important subject for land-atmosphere interaction studies. Recurrent extreme climate events, such as droughts and floods, are important features of the East Asian monsoon, especially over the Yangtze River basin. Xue et al. (2016) demonstrated the important role of the spring surface and subsurface temperature anomalies over

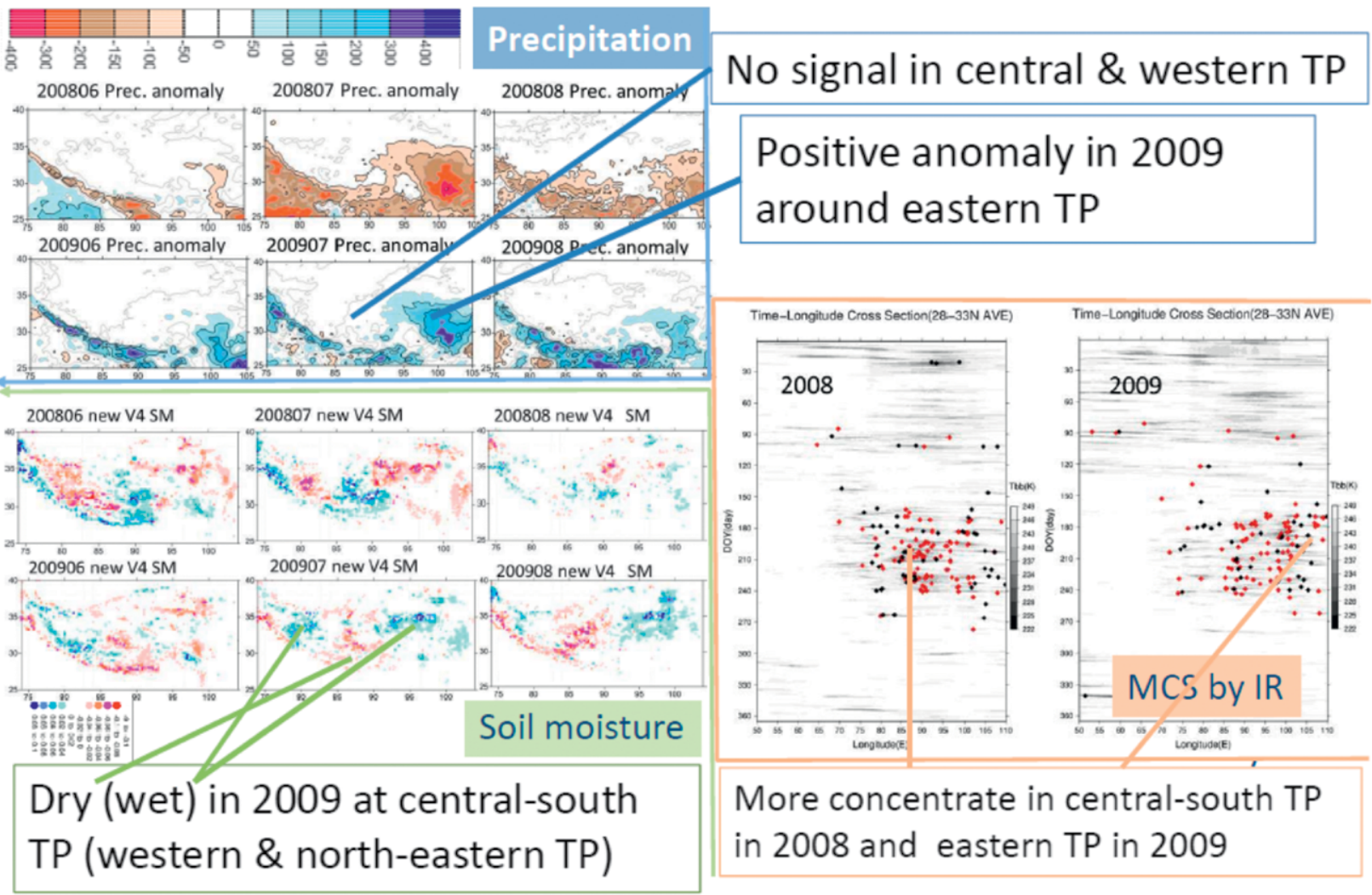

FIG. 4. (top left) Monthly precipitation and (bottom left) soil moisture anomaly from the average over 2008-I0 produced by the Coordinated Asia-European Long-Term Observing System of Qinghai-Tibet Plateau HydroMeteorological Processes and the Asian-Monsoon System with Ground Satellite Image Data and Numerical Simulations (CEOP-AEGIS) project data. (right) Occurrences of daytime (red) and nighttime (black) MCS in $30^{\circ}-31^{\circ} \mathrm{N}$ identified by infrared data are plotted on the day of year (DOY)-longitude diagram with temperature of black body (Tbb; K) distribution. 
the northern Rocky Mountain areas on the late spring-summer droughts/floods in the U.S. southern plains and surrounding areas. Following that approach, observational data analyses and modeling studies have also suggested that the spring surface and subsurface temperature anomalies over the TP have significant effects on the summer drought/ flood in the East Asian lowland plains. Its effect is probably more important than the well-known sea surface temperature effects (Xue et al. 2018). Due to the importance of the S2S prediction, a multimodel experiment under the Global Energy and Water Exchanges project (GEWEX) and TPE support will be conducted to further investigate this issue (Xue et al. 2019). In addition, the TP snow and atmosphere interaction has also been investigated (Seol and Hong 2009; Li et al. 2018; Xiao and Duan 2016).

To approach the next scientific issues of the TP and its future change, it is important to understand the causes and consequences of accelerated warming of the TP regions and make credible future projections for society. For this purpose, multimodel intercomparisons would be very desirable. Future studies need to consider different time scales, such as interannual
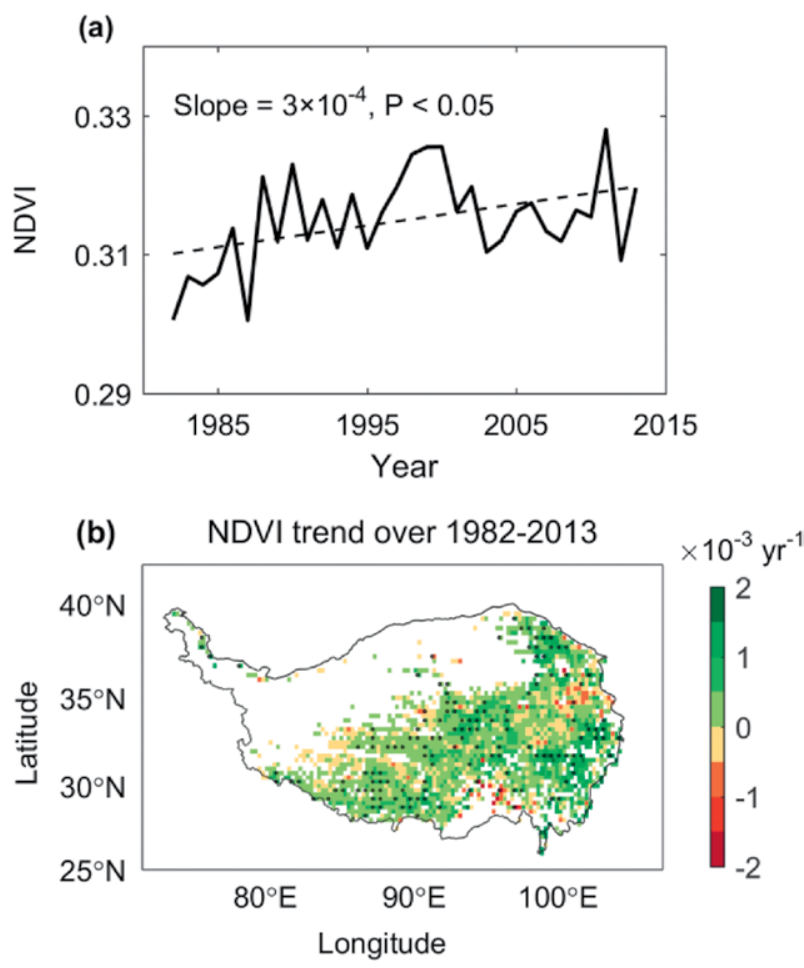

FIG. 5. (a) Interannual variation in mean growing season (May-Sep) grassland normalized difference vegetation index (NDVI) over the TP and (b) spatial distribution of growing season NDVI trends during the period 1982-2013. Pixels with statistically significant difference at the $a<0.05$ level are marked with dots. variability with water resource changes for hazard mitigation and social impact, as well as global warming time scales with glacier/climate/ecosystem changes and paleo time scales. Observational data sharing and cross-cutting discussions with other research groups (e.g., stratosphere, glacier, water resource, ecosystems, aerosol) could be very beneficial. The 2016 Xining workshop provided a very good starting point.

IMPACT ON ECOSYSTEM. There have been significant advances in our understanding of variability and changes in TP spring phenology, movement of tree line, vegetation greening, and vegetation feedback associated with the climate variability and warming over the TP. The recent developments in satellite observations and field measurements have greatly enhanced our ability to understand the response of the ecosystem under a changing climate (e.g., Xiao et al. 2016; Jia et al. 2015; Lettenmaier et al. 2015; Cai et al. 2015). Recent studies have pinpointed the crucial role of precipitation in affecting spring phenology. Figure 5 shows multisource satellite-based phenological observations, which indicate widespread phenological advancing trends in most TP regions, but there is spring phenological delay over the southwest TP mainly due to the recent decline in spring precipitation (Shen et al. 2014; M. G. Shen et al. 2015a). The role of precipitation is further confirmed by the 7-yr spring phenological observations in Kobresia meadows in the central TP, where leaf-unfolding dates of dominant sedge and grass species are synchronized with the arrival of the monsoon rainfall (C. L. Li et al. 2016). Meanwhile, in addition to a number of experiments conducted over the TP that have refreshed our common knowledge on the temperature responses of phenological events, it has also been found that, contrary to the finding from northern high latitudes (Piao et al. 2015), spring phenology over the TP is determined by nighttime temperature (Shen et al. 2016).

The effect of climate warming on ecosystems' structures are often manifested in the movement of alpine tree line over the Qilian Mountains and the Hengduan Mountains of the TP $(\sim 4,900 \mathrm{~m})$. The upslope migration rates, however, were largely determined by interspecific interactions, a crucial biotic factor, with other plants. For instance, within two large rectangular plots in the Sygera Mountains of the southeastern TP, Wang et al. (2016) documented that increased stem density and intraspecific competition reduced the warming-induced upward shift in the alpine tree line. These findings help explain why many tree lines on a global scale have not advanced in response to climatic warming. 


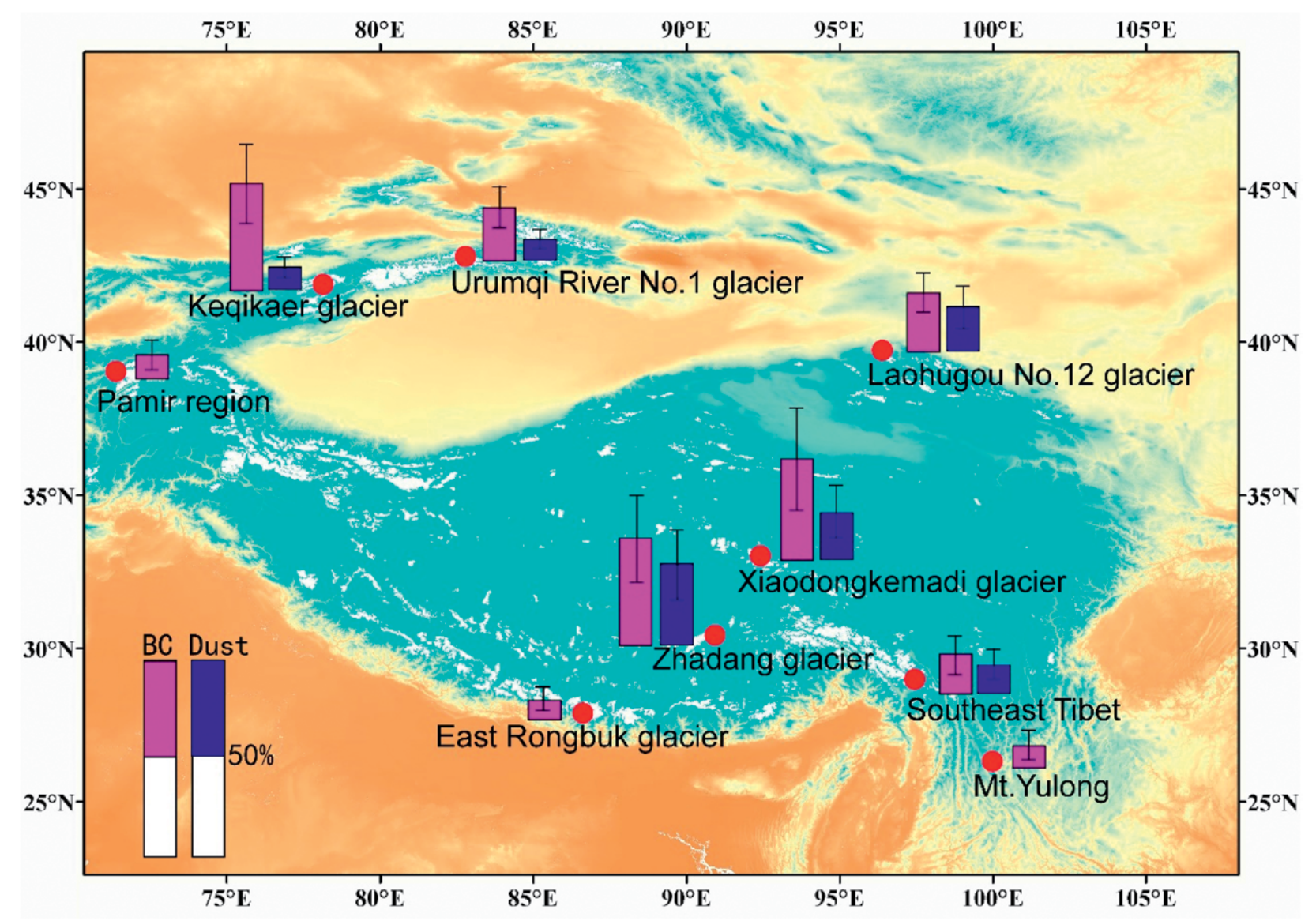

FIG. 6. Contributions of BC (magenta) and dust (blue) in the surface snow of glaciers to the reduction of surface albedo over the TP for the Pamir region (Schmale et al. 20I7), Keqikaer glacier (Zhang et al. 20I7b), Urumqi River No. I glacier (Ming et al. 2016), Laohugou No. I2 glacier (L. Li et al. 20 I6), Xiaodongkemadi glacier (X. F. Li et al. 2017), Zhadang glacier (Qu et al. 2014), East Rongbuk glacier (Ming et al. 2009), southeast Tibet (Zhang et al. 20I7a), and Mt. Yulong (Niu et al. 20I7).

The functioning of ecosystems also experienced changes in past decades. Evidence gleaned from satellite observations, long-term ecological stations, and modeling work have all shown an increase in vegetation growth over the TP during the 1980s, 1990s, and 2000s (Fig. 6; e.g., Piao et al. 2012; Shen et al. 2016). This increase in vegetation growth denoted by the leaf area index (LAI) is mainly attributed to the warming effects instead of the $\mathrm{CO}_{2}$ fertilization effect over the TP (Zhu et al. 2016). However, this strong warming effect over the TP might not be long-lasting since a warming-induced increase in drought and hot extreme days could weaken the temperature response of vegetation productivity in cold ecosystems (Piao et al. 2014).

The response of an ecosystem to climate variability and anthropogenic effect could also be feedback to climate (e.g., Li and Xue 2010). M. G. Shen et al. (2015b) combined satellite observations with a set of regional model simulations, indicating that increased growing season vegetation activity because of warming dampens the daytime warming over the TP due to more evapotranspiration. Recently, J. Li et al. (2017) used multisource satellite observations along with an atmospheric moisture tracking model to show that recent grassland regeneration in the headstream of the Yangtze River over the TP can increase precipitation through local vegetation-precipitation feedback, which, however, does not compensate for the water loss because of enhanced evapotranspiration.

\section{AEROSOL PROCESSES AND THEIR IM- PACTS ON TP CLIMATE AND CRYO-}

SPHERE. Recently there has been a growing set of evidence showing that the atmospheric heating by light-absorbing aerosols [e.g., black carbon (BC) and mineral dust (MD)] and reduction of surface snow/ ice albedo induced by light-absorbing impurities in snowpack and glaciers were partially responsible for the rapid warming and the accelerated glacier retreat over the TP. Meanwhile, studies also show that the 
forcing by aerosols and their impact on regional climate over the TP remain uncertain.

In recent years, additional progress has been achieved in aerosol measurements. In addition to the Aerosol Robotic Network (AERONET) measurements over the TP (Cong et al. 2009), the TRAP-HKT (transport of atmospheric pollutants across HimalayaKarakoram-Tibetan Plateau) Monitoring Network, which consists of 19 sites, has been established over the TP since 2013 to measure the spatial and temporal distributions of some pollutants. The remoteness and high elevation of the Himalayas and TP have often been thought to act as a barrier to stop pollution from reaching the higher glaciated peaks. But recent evidence using satellite and AERONET data show that pollution is spreading over the world's highest mountain range and across inland Tibet (Lüthi et al. 2015; Kang et al. 2016; Cong et al. 2015a,b). According to the $\Delta^{14} \mathrm{C} / d^{13} \mathrm{C}$ compositions, the $\mathrm{BC}$ sources in the Himalayas were found to be contributed by biomass burning (54\% $\pm 11 \%)$ and fossil fuel combustions $(46 \% \pm 11 \%)$, which are similar to the typical source characteristics in Indo-Gangetic Plain. In the remote northern TP, BC originates predominately from fossil fuel combustion from western China (R. C. Li et al. 2016). Long-term dust variation from ice core records suggested that the TP is also a region suffering from frequent dust storms and blowing dust (Kang et al. 2010b; R. Zhang et al. 2015).

Aerosols' roles in the atmosphere are also being investigated. The elevated heat pump (EHP) mechanism over the TP region has been considered as well, to explain the direct and indirect effects of absorbing aerosols on the Indian monsoon (Lau et al. 2008) and other modeling studies (e.g., Gu et al. 2016). Using a coupled regional climate-chemistry model, Ji et al. (2011) showed that the mixed anthropogenic aerosols induced the summer monsoon onset, delaying by 1-2 pentads in central and southeast India and advancing by 1-2 pentads in northeast India and Myanmar. During the monsoon period, the atmospheric carbonaceous aerosols induced warming and cooling of $0.1^{\circ}-0.5^{\circ} \mathrm{C}$ on the TP and South Asia, respectively (Ji et al. 2015).

Furthermore, the discovery of the Asian Tropopause Aerosol Layer (ATAL) from National Aeronautics and Space Administration (NASA) satellite observations and Modern-Era Retrospective Analysis for Research and Applications, version 2 (MERRA-2), reanalysis data has sparked much interest in research

${ }^{1}$ This network has been expanded to Atmospheric Pollution and Cryospheric Change (APCC). on its composition, origin, and relationships to the transport processes of atmospheric constituents in the upper troposphere and lower stratosphere (UTLS) and the variability of the Asian monsoon anticyclone. One of the major pathways for surface aerosol transfer to ATAL is via the strong large-scale vertical motion and convective ascent over the Tibetan-Himalayan foothills during the peak phase of the Asian monsoon. The ATAL is modulated by UTLS transport processes, which undergo intrinsic monsoon intraseasonal oscillations with a $\sim 20-30$-day quasi periodicity, that are coupled to lower-tropospheric monsoon dynamics and diabatic heating processes (Lau et al. 2016).

Besides the effects in the atmosphere, light-absorbing aerosols deposited on the snow cover also affect the regional climate through snow albedo feedback (e.g., Qian et al. 2011; Y. L. Zhang et al. 2015). Equilibrium GCM experiments were conducted by Qian et al. (2011) showing that the snowmelt efficacy induced by $\mathrm{BC}$ in snow is 1-3 times larger for snow cover fraction and 2-4 times larger for snow water equivalent (SWE) than that induced by $\mathrm{CO}_{2}$ increase during April-July. Furthermore, Ji et al. (2016), using an RCM, showed that dust in snow induced surface air temperature to increase by $0.1^{\circ}-0.5^{\circ} \mathrm{C}$ and SWE to decrease by 5-25 mm over the western TP, Pamir, and Kunlun Mountains. BC in snow was found to cause warming of $0.1^{\circ}-1.5^{\circ} \mathrm{C}$ in the western TP and Himalayas. The melting of SWE was over $25 \mathrm{~mm}$ in parts of the aforementioned regions (Ji 2016). The BC forcing also was found to deposit additional solar energy directly onto snow, especially during spring to summer when the net energy on the snowpack is at a maximum.

Evidence also suggested that the rapid retreat of glaciers in the TP is associated with BC deposited in glaciers (Xu et al. 2009; Qu et al. 2014; X. F. Li et al. 2017; Zhang et al. 2017a). Recent studies indicated that $\mathrm{BC}$ and $\mathrm{MD}$ in the surface snow/ice were responsible for about $20 \%$ of the albedo reduction (Fig. 6; Qu et al. 2014; X. F. Li et al. 2017; Schmale et al. 2017; Zhang et al. 2017a). Based on the samples from August 2014 to October 2015 on the Xiaodongkemadi glacier $\left(33^{\circ} 04^{\prime} \mathrm{N}, 92^{\circ} 04^{\prime} \mathrm{E}\right)$ in the central $\mathrm{TP}$ and from four glaciers in the southeastern TP in June 2015 , the instantaneous radiative forcing induced by $\mathrm{BC}$ and $\mathrm{MD}$ in fresh snow was estimated to be about $4.78 \pm 1.27 \mathrm{~W} \mathrm{~m}^{-2}$ in the southeast $\mathrm{TP}$ and $7.09 \pm 2.10 \mathrm{~W} \mathrm{~m}^{-2}$ in the central TP, while for the aged snow or granular ice, instantaneous radiative forcing can reach to near $100 \mathrm{~W} \mathrm{~m}^{-2}$ (X. F. Li et al. 2017; Zhang et al. 2017b). The effects of light-absorbing impurities on albedo reduction and radiative forcing can lead to an average of approximately $15 \%$ of the total glacier 
melt in the southeast TP (Zhang et al. 2017a), and a summer melt rate increase up to $6.3 \%\left(7 \mathrm{~cm} \mathrm{yr}^{-1}\right)$ on the glaciers in Pamir (Schmale et al. 2017).

Aerosol-cloud interactions represent one of the largest uncertainties in global radiative forcing from preindustrial time to the present. There appears to be a significant gap in our knowledge between the smallscale (microphysical) processes and the large-scale (regional/global) events in this area. There remains a need to synthesize multiscale processes and results to identify the problems involved and to improve the current set of observations and models in order to close the gap.

\section{INCREASED GEOHAZARD RISKS UNDER WARMING CLIMATE AND PRIOR TASKS} IN RESEARCH. The TP is highly vulnerable to geohazards like landslides, debris flows, glacial lake outbursts, and snow and ice disasters (Fig. 7a), which often take heavy tolls on human lives and properties and jeopardize major infrastructures. The interplay of intense tectonic activities, complex geomorphology, and climate change tends to trigger these disasters. Warmer climate and stronger human activities over the last decades have made the prospect bleaker (Chen et al. 2015). Growing population and economic intensity in the mountainous TP also add to the region's vulnerability (Cui et al. 2015). In addition to a growing occurrence of traditional catastrophes, new types of disasters are now appearing, adding to the region's worries. In fact, concerns over hazards induced by climate change have surged since the release of the Intergovernmental Panel on Climate Change (IPCC) Fifth Assessment Report (O’Neill et al. 2017).

The TP has experienced significant warming and frequent extreme climate events in the last 50 years (Chen et al. 2015). Warming has left glaciers on the TP in general retreat, which breeds and feeds the glacial lakes and leads to their ultimate outbursts (Bolch et al. 2012; Yao et al. 2012b), and made permafrost structure vulnerable, which causes the unstable slopes and erosion and leads to more frequent landslides and debris flows (Kang et al. 2010a). Glacial lake outburst floods on the TP are growing both in frequency of occurrences and spatial scale (Fig. 7b; Richardson and Reynolds 2000; Yao et al. 2014; Wang et al. 2015). Debris flows tend to be more active as well. For example, the Guxiang gully, a typical glacial debris flow gully, has witnessed $\sim 1,000$ debris flow events since 1953 (X. D. Liu et al. 2013). Meanwhile, new types of disasters have found their way into the region, such as the twin ice avalanches in Ngari in July and September 2016 (Figs. 7c,d; Qiu 2016; Tian et al. 2017). Disasters on the TP tend to have a chain effect, which both prolongs and enlarges their damage (Cui and Jia 2015). A megalandslide occurred in Yigong on 9 April 2000 that blocked the river and formed a natural dam, causing a megaoutburst flood and destroying most roads and bridges downstream (Delaney and Evans 2015).

Currently, research on TP hazards is hindered by 1) the scarcity of observational data, which hinders the development of quantitative models for projection, and 2) insufficient kinetic studies on how disaster chains form and evolve, which frustrates the efforts to understand, predict, and assess mountain hazards.

For the hazard research on the TP, future priorities should be given to the following:

1) Establishing a database on Tibetan Plateau hazards. Future research should extend from current cities, counties, and route-based studies to the regional level and set up a database accordingly. A ready platform for big data analysis should help shed light on the formation and evolution of hazards.

2) Studying quantitative relations between various conditions and triggers of hazards, including climate contributing factors. This effort will lead to model development that can predict future hazard scenarios, including its evolution. To that end, high-temporal and high-spatial resolution remote sensing data should be selected using various techniques.

3) Building kinetic models for TP hazard chain. The $\mathrm{TP}$, especially the plateau margin, is becoming more vulnerable to major disasters and the consequent hazard chains. A physical kinetic model (e.g., Chen and Lee 2003; H. X. Chen et al. 2016) can be very helpful when it comes to integrating processes along the hazard chains such as glacier collapse, glacial lake outburst, landslides, and debris flows, as it can reveal how the chains form and evolve over time and space.

4) Developing an integrative approach for hazard assessment. The multi- and cross-dimensional nature of disasters demands an integrative approach for hazard assessment. Natural hazards put human lives, properties, and crucial infrastructures at risk, which only cooperative mechanisms with diverse representations from governments, the private sector, and the civil society can help prevent and reduce. Such mechanisms will enable nations, communities, and local people to play better-defined roles in disaster risk management, which boosts both efficiency and effectiveness, 


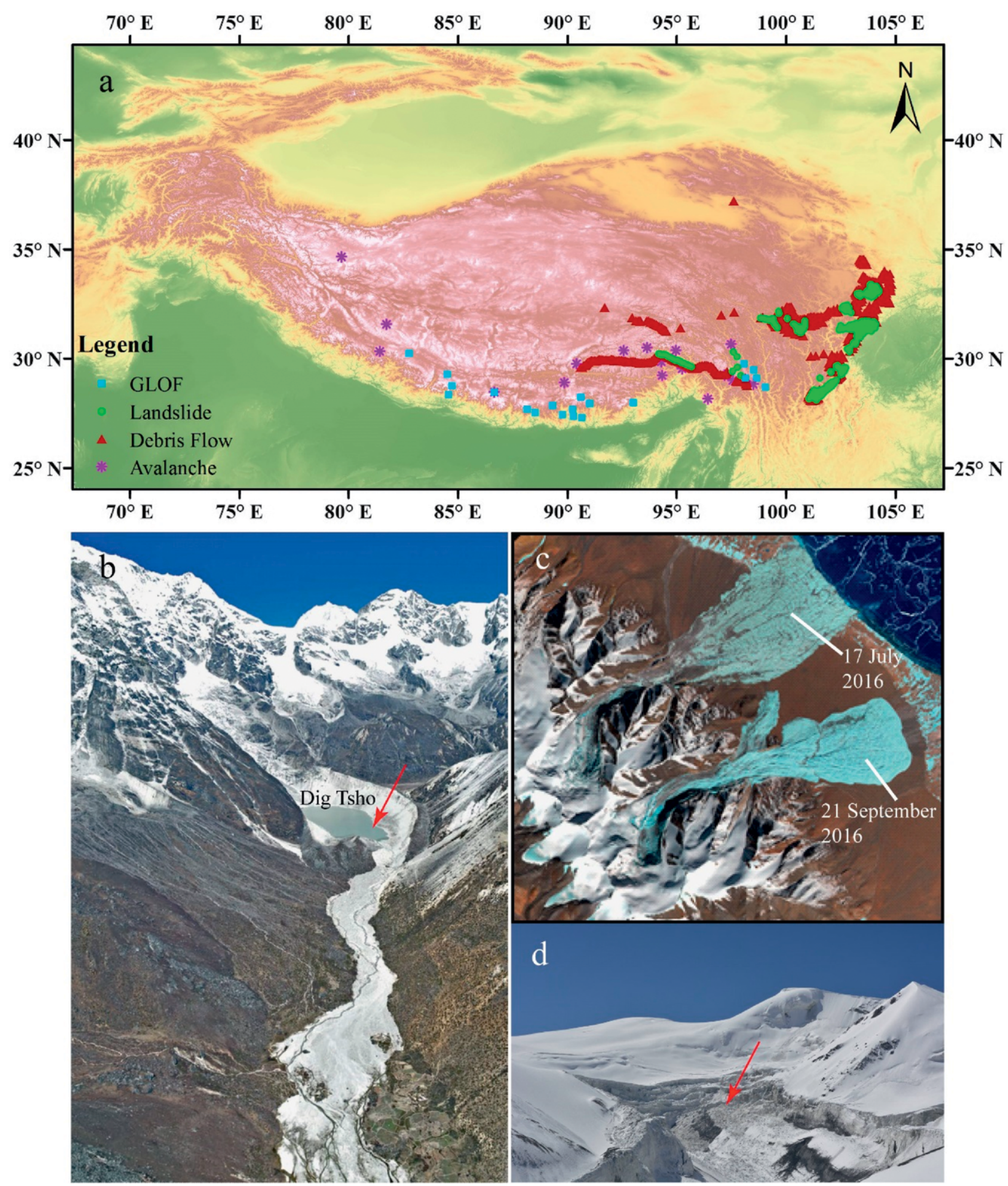

Fig. 7. Hazard risk in the TP. (a) Distribution of major mountain hazards in the TP (modified from Cui and Jia 2015). (b) Aerial view of Dig Tsho (Nepal) on 24 Apr 2009; the 1985 glacial lake outburst flood event caused more than $\$ 3$ million worth of damage and disrupted the downstream community for several months (red arrow indicates the event site; credit: International Centre for Integrated Mountain Development). (c) Sentinel-2 satellite image shows two glaciers collapse in Aru, western Tibet (the dates of the events are listed). (d) The upper valley of Aru glacier collapse site (red arrow indicates the event site; photo by Tandong Yao). 
leading to better implementation of overall management of safety and security issues.

CONCLUSIONS. The recent warming over the $\mathrm{TP}$ is unprecedented in the past 2,000 years and is leading to strong cryospheric melt and intensification of the water cycle, which is accompanied with a greening ecosystem and an increasing frequency of hazards. The land and atmospheric processes over the TP interact with the Asian monsoon and westerlies and influence surroundings areas including East Asia, South Asia, and central Asia. Its broader impact through teleconnection is under investigation. These complex interactions are leading to more challenges in projecting the TP's future environment. To successfully cope with this challenge, major achievements need to be made in order to comprehensively understand the interaction between the Asian monsoon and westerlies, between the climate system and other systems, and between the processes over the TP and linkages to other regions. We therefore need to advance our knowledge by investigating every major component in the TP Earth system, including anthropogenic effect, by using a multidisciplinary approach with observations, modeling, and analyses. The 2016 Xining workshop discussed some key issues in future TP studies. It is imperative to comprehensively evaluate the characteristics of present TP atmosphere, cryosphere, hydrosphere, and biosphere with the latest available TP observational and modeling data from the TPE field measurements, satellite observation, reanalysis data, and other sources, as well as the future potential changes under strong anthropogenic activities. Other important undertakings include developing a better understanding of the mechanisms driving the fast rise of the temperature at higher-elevation regions at present and in the future, water vapor transportation processes of the Asian monsoon and westerlies, aerosols and their impact on regional climate over the TP, the impact of a terrestrial ecosystem on a climate system in response to climate warming, and the local and regional impact of TP land surface changes. The broad and comprehensive presentations and discussions at the Xining workshop in 2016 have stimulated activity for this overview on TP multidisciplinary research. The full workshop program and abstracts of the workshop can be found online (at http://xining2016.tpe.ac.cn/ and https://easmea-outreach.geog.ucla.edu/xining20/6/).

ACKNOWLEDGMENTS. The researchers are supported by the Chinese Academy of Sciences (the Strategic Priority Research Program, Grant XDA20000000, and the Frontier Research Program), the National Natural Science
Foundation of China, the U.S. National Science Foundation Grant AGS-1419526, and many other funding agencies from different countries.

\section{REFERENCES}

Bibi S., L. Wang, X. Li, J. Zhou,D. Chen, and T. Yao, 2018: Climatic and associated cryospheric, biospheric, and hydrological changes on the Tibetan Plateau: A review. Int. J. Climatol., 38 (Suppl.), e1-e17, https:// doi.org/10.1002/joc.5411.

Bolch, T., and Coauthors, 2012: The state and fate of Himalayan glaciers. Science, 336, 310-314, https:// doi.org/10.1126/science.1215828.

Bromwich, D. H., J. P. Nicolas, A. J. Monaghan, M. A. Lazzara, L. M. Keller, G. A. Weidner, and A. B. Wilson, 2013: Central West Antarctica among the most rapidly warming regions on Earth. Nat. Geosci., 6, 139-145, https://doi.org/10.1038/ngeo1671.

Cai, D., K. Fraedrich, F. Sielmann, L. Zhang, X. Zhu, S. Guo, and Y. Guan, 2015: Vegetation dynamics on the Tibetan Plateau (1982-2006): An attribution by ecohydrological diagnostics. J. Climate, 28, 45764584, https://doi.org/10.1175/JCLI-D-14-00692.1.

—, Q. You, K. Fraedrich, and Y. Guan, 2017: Spatiotemporal temperature variability over the Tibetan Plateau: Altitudinal dependence associated with the global warming hiatus. J. Climate, 30, 969-984, https://doi.org/10.1175/JCLI-D-16-0343.1.

Chen, B., W. C. Chao, and X. Liu, 2003: Enhanced climatic warming in the Tibetan Plateau due to doubling $\mathrm{CO}_{2}$ : A model study. Climate Dyn., 20, 401-413, https://doi.org/10.1007/s00382-002-0282-4.

Chen, D. L., and Coauthors, 2015: Assessment of past, present and future environmental changes on the Tibetan Plateau. Chin. Sci. Bull., 60, 3025-3035, https://doi.org/10.1360/N972014-01370.

Chen, H., and C. F. Lee, 2003: A dynamic model for rainfall-induced landslides on natural slopes. Geomorphology, 51, 269-288, https://doi.org/10.1016 /S0169-555X(02)00224-6.

Chen, H., and Coauthors, 2013: The impacts of climate change and human activities on biogeochemical cycles on the Qinghai-Tibetan Plateau. Global Change Biol., 19, 2940-2955, https://doi.org/10.1111 /gcb.12277.

Chen, H. X., S. Zhang, M. Peng, and L. M. Zhang, 2016: A physically-based multi-hazard risk assessment platform for regional rainfall-induced slope failures and debris flows. Eng. Geol., 203, 15-29, https://doi .org/10.1016/j.enggeo.2015.12.009.

Chen, S. B., Y. F. Liu, and A. Thomas, 2006: Climatic change on the Tibetan Plateau: Potential evapotranspiration 
trends from 1961-2000. Climatic Change, 76, 291-319, https://doi.org/10.1007/s10584-006-9080-z.

Chen, X. L., B. Skerlak, M. W. Rotach, J.A. Añel, Z. Su, Y. Ma, and M. Li, 2016: Reasons for the extremely high-ranging planetary boundary layer over the western Tibetan Plateau in winter. J. Atmos. Sci., 73, 2021-2038, https://doi.org/10.1175/JAS-D-15-0148.1.

Chen, Y. Y., K. Yang, J. Qin, Q. Cui, H. Lu, Z. La, M. Han, and W. Tang, 2017: Evaluation of SMAP, SMOS, and AMSR2 soil moisture retrievals against observations from two networks on the Tibetan Plateau. J. Geophys. Res. Atmos., 122, 5780-5792, https://doi .org/10.1002/2016JD026388.

Cheng, G. D., and T. H. Wu, 2007: Responses of permafrost to climate change and their environmental significance, Qinghai-Tibet Plateau. J. Geophys. Res., 112, F02S03, https://doi.org/10.1029/2006JF000631.

Cong, Z., S. Kang, A. Smirnov, and B. Holben, 2009: Aerosol optical properties at Nam Co, a remote site in central Tibetan Plateau. Atmos. Res., 92, 42-48, https://doi.org/10.1016/j.atmosres.2008.08.005.

_ , _ - K. Kawamura, B. Liu, X. Wan, Z. Wang, S. Gao, and P. Fu, 2015a: Carbonaceous aerosols on the south edge of the Tibetan Plateau: Concentrations, seasonality and sources. Atmos. Chem. Phys., 15, 1573-1584, https://doi.org/10.5194/acp-15-1573 -2015 .

- K. Kawamura, S. C. Kang, and P. Fu, 2015b: Penetration of biomass-burning emissions from South Asia through the Himalayas: New insights from atmospheric organic acids. Sci. Rep., 5, 9580, https:// doi.org/10.1038/srep09580.

Cui, P., and Y. Jia, 2015: Mountain hazards in the Tibetan Plateau: Research status and prospects. Natl. Sci. Rev., 2, 397-399, https://doi.org/10.1093/nsr/nwv061.

—, F. H. Su, Q. Zou, N. S. Chen, and Y. L. Zhang, 2015: Risk assessment and disaster reduction strategies for mountainous and meteorological hazards in Tibetan Plateau. Chin. Sci. Bull., 60, 3067-3077, https://doi .org/10.1360/N972015-00849.

Cui, X. F., and H. F. Graf, 2009: Recent land cover changes on the Tibetan Plateau: A review. Climatic Change, 94, 47-61, https://doi.org/10.1007/s10584 -009-9556-8.

Cuo, L., Y. Zhang, F. Zhu, and L. Liang, 2014: Characteristics and changes of streamflow on the Tibetan Plateau: A review. J. Hydrol.: Reg. Stud., 2, 49-68, https://doi.org/10.1016/j.ejrh.2014.08.004.

Dansgaard, W., 1964: Stable isotope in precipitation. Tellus, 14, 436-468, https://doi.org/10.3402/tellusa .v16i4.8993.

Delaney, K. B., and S. G. Evans, 2015: The 2000 Yigong landslide (Tibetan Plateau), rockslide-dammed lake and outburst flood: Review, remote sensing analysis, and process modelling. Geomorphology, 246, 377-393, https://doi.org/10.1016/j.geo morph.2015.06.020.

Dozier, J., E. H. Bair, and R. E. Davis, 2016: Estimating the spatial distribution of snow water equivalent in the world's mountains. Wiley Interdiscip. Rev.: Water, 3, 461-474, https://doi.org/10.1002/wat2.1140.

Du, M. Y., S. Kawashima, S. Yonemura, X. Zhang, and S. Chen, 2004: Mutual influence between human activities and climate change in the Tibetan Plateau during recent years. Global Planet. Change, 41, 241249, https://doi.org/10.1016/j.gloplacha.2004.01.010.

Duan, A. M., and G. X. Wu, 2006: Change of cloud amount and the climate warming on the Tibetan Plateau. Geophys. Res. Lett., 33, L22704, https://doi .org/10.1029/2006GL027946.

- and Z. X. Xiao, 2015: Does the climate warming hiatus exist over the Tibetan Plateau? Sci. Rep., 5, 13711, https://doi.org/10.1038/srep13711.

_-, G. X. Wu, Q. Zhang, and Y. Liu, 2006: New proofs of the recent climate warming over the Tibetan Plateau as a result of the increasing greenhouse gases emissions. Chin. Sci. Bull., 51, 1396-1400, https:// doi.org/10.1007/s11434-006-1396-6.

Frauenfeld, O. W., T. J. Zhang, and M. C. Serreze, 2005: Climate change and variability using European Centre for Medium-Range Weather Forecasts reanalysis (ERA-40) temperatures on the Tibetan Plateau. J. Geophys. Res., 110, D02101, https://doi .org/10.1029/2004JD005230.

Gao, Y. H., X. Li, L. R. Leung, D. Chen, and J. Xu, 2015: Aridity changes in the Tibetan Plateau in a warming climate. Environ. Res. Lett., 10, 034013, https://doi .org/10.1088/1748-9326/10/3/034013.

Ge, F., F. Sielmann, X. Zhu, K. Fraedrich, X. Zhi, T. Peng, and L. Wang, 2017: The link between Tibetan Plateau monsoon and Indian summer precipitation: A linear diagnostic perspective. Climate Dyn., 49, 4201-4215, https://doi.org/10.1007/s00382-017-3585-1.

Gu, Y., Y. Xue, F. De Sales, and K. N. Liou, 2016: A GCM investigation of dust aerosol impact on the regional climate of North Africa and South/East Asia. Climate Dyn., 46, 2353-2370, https://doi.org/10.1007 /s00382-015-2706-y.

Guo, D. L., and H. J. Wang, 2012: The significant climate warming in the northern Tibetan Plateau and its possible causes. Int. J. Climatol., 32, 1775-1781, https:// doi.org/10.1002/joc.2388.

—, and — 2013: Simulation of permafrost and seasonally frozen ground conditions on the Tibetan Plateau, 1981-2010. J. Geophys. Res. Atmos., 118, 5216-5230, https://doi.org/10.1002/jgrd.50457. 
Hong, S. Y., M. Kanamitsu, J. E. Kim, and M.-S. Koo, 2012: Effects of diurnal cycle on a simulated Asian summer monsoon. J. Climate, 25, 8394-8408, https:// doi.org/10.1175/JCLI-D-12-00069.1.

Huang, X. D., J. Deng, X. F. Ma, Y. Wang, Q. Feng., X. Hao, and T. Liang, 2016: Spatiotemporal dynamics of snow cover based on multi-source remote sensing data in China. Cryosphere, 10, 2453-2463, https://doi .org/10.5194/tc-10-2453-2016.

Immerzeel, W. W., L. P. H. Van Beek, and M F P. Bierkens, 2010: Climate change will affect the Asian water towers. Science, 328, 1382-1385, https://doi .org/10.1126/science.1183188.

— — _ M. Konz, A. B. Shrestha, and M. F. P. Bierkens, 2012: Hydrological response to climate change in a glacierized catchment in the Himalayas. Climatic Change, 110, 721-736, https://doi .org/10.1007/s10584-011-0143-4.

Ji, Z. M., 2016: Modeling black carbon and its potential radiative effects over the Tibetan Plateau. Adv. Climate Change Res., 7, 139-144, https://doi .org/10.1016/j.accre.2016.10.002.

_ , S. C. Kang, D. F. Zhang, C. Zhu, J. Wu, and Y. Xu, 2011: Simulation of the anthropogenic aerosols over South Asia and their effects on Indian summer monsoon. Climate Dyn., 36, 1633-1647, https://doi .org/10.1007/s00382-010-0982-0.

,,-- Z. Y. Cong, Q. Zhang, and T. Yao, 2015: Simulation of carbonaceous aerosols over the Third Pole and adjacent regions: Distribution, transportation, deposition, and climatic effects. Climate Dyn., 45, 2831-2846, https://doi.org/10.1007/s00382-015 $-2509-1$.

,-- , Q. G. Zhang, Z. Cong, P. Chen, and M. Sillanpää, 2016: Investigation of mineral aerosols radiative effects over High Mountain Asia in 1990-2009 using a regional climate model. Atmos. Res., 178-179, 484496, https://doi.org/10.1016/j.atmosres.2016.05.003.

Jia, K., and Coauthors, 2015: Global land surface fractional vegetation cover estimation using general regression neural networks from MODIS surface reflectance. IEEE Trans. Geosci. Remote Sens., 53, 47874796, https://doi.org/10.1109/TGRS.2015.2409563.

Johnsen, S. J., W. Dansgaard, and J. W. White, 1989: The origin of Arctic precipitation under present and glacial condition. Tellus, 41B, 452-468, https://doi .org/10.3402/tellusb.v41i4.15100.

Jones, P. D., D. H. Lister, T. J. Osborn, C. Harpham, M. Salmon, and C. P. Morice, 2012: Hemispheric and large-scale land surface air temperature variations: An extensive revision and an update to 2010. J. Geophys. Res., 117, D05127, https://doi. org/10.1029/2011JD017139.
Jungclaus, J. H., and Coauthors, 2017: The PMIP4 contribution to CMIP6-Part 3: The last millennium, scientific objective, and experimental design for the PMIP4 past1000 simulations. Geosci. Model Dev., 10, 4005-4033, https://doi.org/10.5194/gmd -10-4005-2017.

Kageyama, M., and Coauthors, 2018: The PMIP4 contribution to CMIP6 - Part 1: Overview and over-arching analysis plan. Geosci. Model Dev., 11, 1033-1057, https://doi.org/10.5194/gmd-11-1033-2018.

Kuang, X. X., and J. J. Jiao, 2016: Review on climate change on the Tibetan Plateau during the last half century. J. Geophys. Res. Atmos., 121, 3979-4007, https://doi.org/10.1002/2015JD024728.

Kang, S. C., Y. W. Xu, Q. L. You, W.-A. Flügel, N. Pepin, and T. Yao, 2010a: Review of climate and cryospheric change in the Tibetan Plateau. Environ. Res. Lett., 5, 015101, https://doi.org/10.1088/1748-9326/5/1/015101.

_ , Y. L. Zhang, Y. J. Zhang, B. Grigholm, S. Kaspari, D. Qin, J. Ren, and P. Mayewski, 2010b: Variability of atmospheric dust loading over the central Tibetan Plateau based on ice core glaciochemistry. Atmos. Environ., 44, 2980-2989, https://doi.org/10.1016/j .atmosenv.2010.05.014.

— , P. F. Chen, C. L. Li, B. Liu, and Z. Cong, 2016: Atmospheric aerosol elements over the inland $\mathrm{Ti}$ betan Plateau: Concentration, seasonality, and transport. Aerosol Air Qual. Res., 16, 789-800, https://doi .org/10.4209/aaqr.2015.05.0307.

Lau, K., and Coauthors, 2008: The Joint Aerosol-Monsoon Experiment: A new challenge for monsoon climate research. Bull. Amer. Meteor. Soc., 89, 369-384, https://doi.org/10.1175/BAMS-89-3-369.

Lau, W. K.-M., C. Yuan, and Z. Li, 2016: Tibetan Anticyclone, Asian Tropopause Aerosol Layer (ATAL) and transport processes in the upper troposphere and lower stratosphere (UTLS). Int. Workshop on Land Surface Multi-Spheres Processes of Tibetan Plateau and Their Environmental and Climate Effects Assessment, Xining, China, TPE/ITPCAS/UCLA, http:// xining2016.tpe.ac.cn/dct/page/1.

Lei, Y. B., K. Yang, B. Wang, Y. Sheng, B. W. Bird, G. Zhang, and L. Tian, 2014: Response of inland lake dynamics over the Tibetan Plateau to climate change. Climatic Change, 125, 281-290, https://doi .org/10.1007/s10584-014-1175-3.

Lettenmaier, D. P., D. Alsdorf, J. Dozier, G. J. Huffman, M. Pan, and W. Wood, 2015: Inroads of remote sensing into hydrologic science during the WRR era. Water Resour. Res., 51, 7309-7342, https://doi .org/10.1002/2015WR017616.

Li, C. L., and Coauthors, 2016: Sources of black carbon to the Himalayan-Tibetan Plateau glaciers. 
Nat. Commun., 7, 12574, https://doi.org/10.1038 /ncomms12574.

Li, J., and Coauthors, 2017: Grassland restoration reduces water yield in the headstream region of Yangtze River. Sci. Rep., 7, 2162, https://doi.org /10.1038/s41598-017-02413-9.

Li, L., R. Zhang, and M. Wen, 2011: Diagnostic analysis of the evolution mechanism for a vortex over the Tibetan Plateau in June 2008. Adv. Atmos. Sci., 28, 797-808, https://doi.org/10.1007/s00376-010-0027-y.

$-, \ldots, \ldots$, and L. Liu, 2014a: Effect of the atmospheric heat source on the development and eastward movement of the Tibetan Plateau vortices. Tellus, 66A, 24451, https://doi.org/10.3402/tellusa .v66.24451.

,-- , and,$- 2014 \mathrm{~b}$ : Diurnal variation in the occurrence frequency of the Tibetan Plateau vortices. Meteor. Atmos. Phys., 125, 135-144, https://doi .org/10.1007/s00703-014-0325-5.

,-- , and — -2017 : Genesis of southwest vortices and its relation to Tibetan Plateau vortices. Quart. J. Roy. Meteor. Soc., 143, 2556-2566, https://doi .org/10.1002/qj.3106.

Li, Q., and Y. K. Xue, 2010: Simulated impacts of land cover change on summer climate in Tibetan Plateau. Environ. Res. Lett., 5, 015102, https://doi .org/10.1088/1748-9326/5/1/015102.

Li, R. C., T. X. Luo, T. Mölg, J. Zhao, X. Li, X. Cui, M. Du, and Y. Tang, 2016: Leaf unfolding of Tibetan alpine meadows captures the arrival of monsoon rainfall. Sci. Rep., 6, 20985, https://doi.org/10.1038 /srep20985.

Li, W., W. Guo, B. Qiu, Y. Xue, P.-C. Hsu, and J. Wei, 2018: Influence of Tibetan Plateau snow cover on East Asian atmospheric circulation at mediumrange time scales. Nat. Commun., 9, 4243, https://doi .org/10.1038/s41467-018-06762-5.

Li, X. F., and Coauthors, 2017: Light-absorbing impurities accelerate glacier melt in the Central Tibetan Plateau. Sci. Total Environ., 587-588, 482-490, https:// doi.org/10.1016/j.scitotenv.2017.02.169.

Li, X. N., and Coauthors, 2016: Responses of sequential and hierarchical phenological events to warming and cooling in alpine meadows. Nat. Commun., 7, 12489, https://doi.org/10.1038/ncomms12489.

Li, X. P., L. Wang, X. Guo, and D. Chen, 2017: Does summer precipitation trend over and around the Tibetan Plateau depend on elevation? Int. J. Climatol., 37 (Suppl.), 1278-1284, https://doi.org/10.1002 /joc. 4978.

Li, Y., and Coauthors, 2016: Impacts of black carbon and mineral dust on radiative forcing and glacier melting during summer in the Qilian Mountains, northeastern Tibetan Plateau. Cryosphere Discuss., https://doi.org/10.5194/tc-2016-32.

Lin, H. B., Q. L. You, Y. Q. Zhang, Y. Jiao, and K. Fraedrich, 2016: Impact of large-scale circulation on the water vapour balance of the Tibetan Plateau in summer. Int. J. Climatol., 36, 4213-4221, https:// doi.org/10.1002/joc.4626.

Liu, J. K., Z. L. Cheng, and Q. H. Li, 2013: Meteorological conditions for frequent debris flows from Guxiang Glacier, Mount Nyenchen Tanglha, China. Mt. Res. Dev., 33, 95-102, https://doi.org/10.1659/MRD -JOURNAL-D-12-00053.1.

Liu, X. D., and B. D. Chen, 2000: Climatic warming in the Tibetan Plateau during recent decades. Int. J. Climatol., 20, 1729-1742, https://doi.org/10.1002/10970088(20001130)20:14<1729::AID-JOC556>3.0.CO;2$\mathrm{Y}$.

_, Z. G. Cheng, L. B. Yan, and Z.-Y. Yin, 2009: Elevation dependency of recent and future minimum surface air temperature trends in the Tibetan Plateau and its surroundings. Global Planet. Change, 68, 164-174, https://doi.org/10.1016/j .gloplacha.2009.03.017.

Liu, Y., Z. S. An, H. W. Linderholm, D. L. Chen, H. M. Song, Q. F. Cai, J. Y. Sun, and H. Tian, 2009: Annual temperatures during the last 2485 years in the mideastern Tibetan Plateau inferred from tree rings. Sci. China, 52D, 348-359, https://doi.org/10.1007 /s11430-009-0025-z.

Liu, Y. M., J. Hu, B. He, Q. Bao, A. Duan, and G. Wu, 2013: Seasonal evolution of subtropical anticyclones in the climate system model FGOALS-s2. Adv. Atmos. Sci., 30, 593-606, https://doi.org/10.1007 /s00376-012-2154-0.

Lüthi, Z. L., B. Škerlak, S. W. Kim, A. Lauer, A. Mues, M. Rupakheti, and S. Kang, 2015: Atmospheric brown clouds reach the Tibetan Plateau by crossing the Himalayas. Atmos. Chem. Phys., 15, 6007-6021, https://doi.org/10.5194/acp-15-6007-2015.

Ma, D., W. Boos, and Z. M. Kuang, 2014: Effects of orography and surface heat fluxes on the South Asian summer monsoon. J. Climate, 27, 6647-6659, https:// doi.org/10.1175/JCLI-D-14-00138.1.

Ma, W. Q., and Y. M. Ma, 2016: Modeling the influence of land surface flux on the regional climate of the Tibetan Plateau. Theor. Appl. Climatol., 125, 45-52, https://doi.org/10.1007/s00704-015-1495-x.

Meehl, G. A., and Coauthors, 2007: Global climate projections. Climate Change 2007: The Physical Science Basis, S. Solomon et al., Eds., Cambridge University Press, 747-845.

Ming, J., C. D. Xiao, H. Cachier, D. Qin, X. Qin, Z. Li, and J. Pu, 2009: Black Carbon (BC) in the snow 
of glaciers in west China and its potential effects on albedos. Atmos. Res., 92, 114-123, https://doi .org/10.1016/j.atmosres.2008.09.007.

—_ — _ F. T. Wang, Z. Li, and Y. Li, 2016: Grey Tienshan Urumqi Glacier No.1 and light-absorbing impurities. Environ. Sci. Pollut. Res., 23, 9549-9558, https://doi.org/10.1007/s11356-016-6182-7.

Niu, H. W., and Coauthors, 2017: Distribution of lightabsorbing impurities in snow of glacier on Mt. Yulong, southeastern Tibetan Plateau. Atmos. Res., 197, 474484, https://doi.org/10.1016/j.atmosres.2017.07.004.

Niu, T., L. X. Chen, and Z. J. Zhou, 2004: The characteristics of climate change over the Tibetan Plateau in the last 40 years and the detection of climatic jumps. Adv. Atmos. Sci., 21, 193-203, https://doi.org/10.1007 /BF02915705.

O'Neill, B. C., and Coauthors, 2017: IPCC reasons for concern regarding climate change risks. Nat. Climate Change, 7, 28-37, https://doi.org/10.1038 /nclimate3179.

Oku, Y., H. Ishikawa, S. Haginoya, and Y. Ma, 2006: Recent trends in land surface temperature on the Tibetan Plateau. J. Climate, 19, 2995-3003, https:// doi.org/10.1175/JCLI3811.1.

Peng, X. Q., T. J. Zhang, O. W. Frauenfeld, K. Wang, B. Cao, X. Zhong, H. Su, and C. Mu, 2017: Response of seasonal soil freeze depth to climate change across China. Cryosphere, 11, 1059-1073, https://doi.org /10.5194/tc-11-1059-2017.

Pepin, N., and Coauthors, 2015: Elevation-dependent warming in mountain regions of the world. Nat. Climate Change, 5, 424-430, https://doi.org/10.1038 /nclimate 2563 .

Piao, S. L., and Coauthors, 2010: The impacts of climate change on water resources and agriculture in China. Nature, 467, 43-51, https://doi.org/10.1038 /nature09364.

_- K. Tan, H. J. Nan, P. Ciais, J. Fang, T. Wang, N. Vuichard, and B. Zhu, 2012: Impacts of climate and $\mathrm{CO}_{2}$ changes on the vegetation growth and carbon balance of Qinghai-Tibetan grasslands over the past five decades. Global Planet. Change, 98-99, 7380, https://doi.org/10.1016/j.gloplacha.2012.08.009.

—_, and Coauthors, 2014: Evidence for a weakening relationship between interannual temperature variability and northern vegetation activity. Nat. Commun., 5, 5018, https://doi.org/10.1038/ncomms6018.

- , and Coauthors, 2015: Leaf onset in the Northern Hemisphere triggered by daytime temperature. Nat. Commun., 6, 6911, https://doi.org/10.1038 /ncomms7911.

Qian, Y., M. G. Flanner, L. R. Leung, and W. Wang, 2011: Sensitivity studies on the impacts of Tibetan Plateau snowpack pollution on the Asian hydrological cycle and monsoon climate. Atmos. Chem. Phys., 11, 1929-1948, https://doi.org/10.5194/acp-11-1929-2011. Qin, D. H., S. Y. Liu, and P. J. Li, 2006: Snow cover distribution, variability, and response to climate change in western China. J. Climate, 19, 1820-1833, https:// doi.org/10.1175/JCLI3694.1.

Qin, J., K. Yang, S. L. Liang, and X. Guo, 2009: The altitudinal dependence of recent rapid warming over the Tibetan Plateau. Climatic Change, 97, 321-327, https://doi.org/10.1007/s10584-009-9733-9.

Qiu, J., 2016: Giant, deadly ice slide baffles researchers. Nature, https://doi.org/10.1038/nature.2016.20471.

Qu, B., and Coauthors, 2014: The decreasing albedo of the Zhadang glacier on western Nyainqentanglha and the role of light-absorbing impurities. Atmos. Chem. Phys., 14, 11 117-11 128, https://doi .org/10.5194/acp-14-11117-2014.

Rangwala, I., J. R. Miller, and M. Xu, 2009: Warming in the Tibetan Plateau: Possible influences of the changes in surface water vapor. Geophys. Res. Lett., 36, L06703, https://doi.org/10.1029/2009GL037245.

— - , G. L. Russell, and M. Xu, 2010: Using a global climate model to evaluate the influences of water vapor, snow cover and atmospheric aerosol on warming in the Tibetan Plateau during the twentyfirst century. Climate Dyn., 34, 859-872, https://doi .org/10.1007/s00382-009-0564-1.

Richardson, S. D., and J. M. Reynolds, 2000: An overview of glacial hazards in the Himalayas. Quat. Int., 65-66, 31-47, https://doi.org/10.1016/S1040 -6182(99)00035-X.

Schmale, J., and Coauthors, 2017: Modulation of snow reflectance and snowmelt from Central Asian glaciers by anthropogenic black carbon. Sci. Rep., 7, 40501, https://doi.org/10.1038/srep40501.

Seol, K. H., and S. Y. Hong, 2009: Relationship between the Tibetan Snow in spring and the East Asian summer monsoon in 2003: A global and regional modeling study. J. Climate, 22, 2095-2110, https:// doi.org/10.1175/2008JCLI2496.1.

Seto, R., T. Koike, and M. Rasmy, 2013: Analysis of the vertical structure of the atmospheric heating process and its seasonal variation over the Tibetan Plateau using a land data assimilation system. $J$. Geophys. Res. Atmos., 118, 12 403-12 421, https://doi .org/10.1002/2013JD020072.

Shen, M. G., G. X. Zhang, N. Cong, S. Wang, W. Kong, and S. Piao, 2014: Increasing altitudinal gradient of spring vegetation phenology during the last decade on the Qinghai-Tibetan Plateau. Agric. For. Meteor., 189-190, 71-80, https://doi.org/10.1016/j .agrformet.2014.01.003. 
—, S. L. Piao, N. Cong, G. Zhang, and I. A. Janssens, 2015a: Precipitation impacts on vegetation spring phenology on the Tibetan Plateau. Global Change Biol., 21, 3647-3656, https://doi.org/10.1111/gcb.12961.

_ - and Coauthors, 2015b: Evaporative cooling over the Tibetan Plateau induced by vegetation growth. Proc. Natl. Acad. Sci. USA, 112, 9299-9304, https:// doi.org/10.1073/pnas.1504418112.

— S. L. Piao, X. Q. Chen, S. An, Y. H. Fu, S. Wang, N. Cong, and I. A. Janssens, 2016: Strong impacts of daily minimum temperature on the green-up date and summer greenness of the Tibetan Plateau. Global Change Biol., 22, 3057-3066, https://doi.org/10.1111 /gcb.13301.

Shen, S. S. P., R. Z. Yao, J. Ngo, A. M. Basist, N. Thomas, and T. Yao, 2015: Characteristics of the Tibetan Plateau snow cover variations based on daily data during 1997-2011. Theor. Appl. Climatol., 120, 445-453, https://doi.org/10.1007/s00704-014-1185-0.

Sheng, Y., 2014: Endorheic lake dynamics: Remote sensing. Encyclopedia of Natural Resources, Y. Wang, Ed., Taylor \& Francis, 687-695.

_- and J. Li, 2011: Satellite-observed endorheic lake dynamics across the Tibetan Plateau between circa 1976 and 2000. Remote Sensing of Protected Lands, Y. Wang, Ed., CRC Press, 305-319.

Song, C., T. Pei, and C. H. Zhou, 2014: The role of changing multiscale temperature variability in extreme temperature events on the eastern and central Tibetan Plateau during 1960-2008. Int. J. Climatol., 34, 3683-3701, https://doi.org/10.1002/joc.3935.

Song, J. H., H. S. Kang, Y. H. Byun, and S. Hong, 2010: Effects of the Tibetan Plateau on the Asian summer monsoon: A numerical case study using a regional climate model. Int. J. Climatol., 30, 743-759, https:// doi.org/10.1002/joc.1906.

Steig, E. J., D. P. Schneider, S. D. Rutherford, M. E. Mann, J. C. Comiso, and D. T. Shindell, 2009: Warming of the Antarctic ice-sheet surface since the 1957 International Geophysical Year. Nature, 457, 459-462, https://doi.org/10.1038/nature07669.

Sugimoto, S., and K. Ueno, 2010: Formation of mesoscale convective systems over the eastern $\mathrm{Ti}$ betan Plateau affected by plateau-scale heating contrasts. J. Geophys. Res., 115, D16105, https://doi .org/10.1029/2009JD013609.

Tamura, T., and T. Koike, 2010: Role of convective heating in the seasonal evolution of the Asian summer monsoon. J. Geophys. Res., 115, D14103, https://doi .org/10.1029/2009JD013418.

Thompson, L. G., 2017: Past, present and future of glacier archives from the world's highest mountains. Proc. Amer. Philos. Soc., 161 (3), 226-243.
—- and Coauthors, 1997: Tropical climate instability: The last glacial cycle from a Qinghai-Tibetan ice core. Science, 276, 1821-1825, https://doi.org/10.1126 /science.276.5320.1821.

- Y. Tandong, M. E. Davis, E. Mosely-Thompson, T. A. Mashiotta, P.-N. Lin, V. N. Mikhalenko, and V. S. Zagorodnov, 2006: Holocene climate variability archived in the Puruogangri ice cap on the central Tibetan Plateau. Ann. Glaciol., 43, 61-69, https://doi .org/10.3189/172756406781812357.

—, and Coauthors, 2018: Ice core records of climate variability on the Third Pole with emphasis on the Guliya ice cap, western Kunlun Mountains. Quat. Sci. Rev., 188, 1-14, https://doi.org/10.1016/j.quascirev 2018.03.003.

Tian, L., T. Yao, P. F. Schuster, J. W. C. White, K. Ichiyanagi, E. Pendall, J. Pu, and W. Yu, 2003: Oxygen-18 concentrations in recent precipitation and ice cores on the Tibetan Plateau. J. Geophys. Res., 108, 4293, https://doi.org/10.1029/2002JD002173.

Tian, L. D., and Coauthors, 2017: Two glaciers collapse in western Tibet. J. Glaciol., 63, 194-197, https://doi .org/10.1017/jog.2016.122.

Ueno, K., and Coauthors, 2016: Linkage of surface condition anomalies and precipitation system observed by CEOP-AEGIS project. Int. Workshop on Land Surface Multi-Spheres Processes of Tibetan Plateau and Their Environmental and Climate Effects Assessment, Xining, China, TPE/ITPCAS/UCLA, http:// xining2016.tpe.ac.cn/dct/page/1.

Wang, B., Q. Bao, B. Hoskins, G. Wu, and Y. Liu, 2008: Tibetan plateau warming and precipitation changes in East Asia. Geophys. Res. Lett., 35, L14702, https:// doi.org/10.1029/2008GL034330.

Wang L., and Coauthors, 2017: Development of a land surface model with coupled snow and frozen soil physics. Water Resour. Res., 53, 5085-5103, https:// doi.org/10.1002/2017WR020451.

Wang, W. C., Y. Xiang, Y. Gao, A. Lu, and T. Yao, 2015: Rapid expansion of glacial lakes caused by climate and glacier retreat in the Central Himalayas. Hydrol. Processes, 29, 859-874, https://doi.org/10.1002/hyp.10199.

Wang, Y. F., N. Pederson, A. M. Ellison, H. L. Buckley, B. S. Case, E. Liang, and J. J. Camarero, 2016: Increased stem density and competition may diminish the positive effects of warming at alpine treeline. Ecology, 97, 1668-1679, https://doi.org/10.1890/15-1264.1.

Wu, G. X., H. F. Zhuo, Z. Q. Wang, and Y. M. Liu, 2016: Two types of summertime heating over the Asian large-scale orography and excitation of potentialvorticity forcing I. Over Tibetan Plateau. Sci. China Earth Sci., 59, 1996-2008, https://doi.org/10.1007 /s11430-016-5328-2. 
Xiao, Z. Q., S. Liang, J. Wang, Y. Xiang, X. Zhao, and J. Song, 2016: Long-time-series global land surface satellite leaf area index product derived from MODIS and AVHRR surface reflectance. IEEE Trans. Geosci. Remote Sens., 54, 5301-5318, https://doi.org/10.1109 /TGRS.2016.2560522.

Xiao, Z. X., and A. Duan, 2016: Impacts of Tibetan Plateau snow cover on the interannual variability of the East Asian summer monsoon. J. Climate, 29, 84958514, https://doi.org/10.1175/JCLI-D-16-0029.1.

Xie, H., and X. Zhu, 2013: Reference evapotranspiration trends and their sensitivity to climatic change on the Tibetan Plateau (1970-2009). Hydrol. Processes, 27, 3685-3693, https://doi.org/10.1002/hyp.9487.

$\mathrm{Xu}, \mathrm{B}$. Q., and Coauthors, 2009: Black soot and the survival of Tibetan glaciers. Proc. Natl. Acad. Sci. USA, 106, 22 114-22 118, https://doi.org/10.1073/pnas .0910444106.

Xu, W. X., and X. D. Liu, 2007: Response of vegetation in the Qinghai-Tibet Plateau to global warming. Chin. Geogr. Sci., 17, 151-159, https://doi.org/10.1007 /s11769-007-0151-5.

Xu, Y., Y. H. Ding, and L. D. Li, 2003: Climatic change projection in Qinghai-Xizang Plateau in the future 100 years. Plateau Meteor., 22 (5), 451-457.

Xue, Y. K., F. De Sales, R. Vasic, C. R. Mechoso, S. D. Prince, and A. Arakawa, 2010: Global and temporal characteristics of seasonal climate/vegetation biophysical process (VBP) interactions. J. Climate, 23, 1411-1433, https://doi.org/10.1175/2009JCLI3054.1.

_ - and Coauthors, 2016: Spring land temperature anomalies in northwestern US and the summer drought over Southern Plains and adjacent areas. Environ. Res. Lett., 11, 059502, https://doi.org/10 .1088/1748-9326/11/4/044018.

—, Y. Ma, and Q. Li, 2017: Land-climate interaction over the Tibetan Plateau. Oxford Research Encyclopedia of Climate Science, https://doi.org/10.1093 /acrefore/9780190228620.013.592.

_ - and Coauthors, 2018: Spring land surface and subsurface temperature anomalies and subsequent downstream late spring-summer droughts/floods in North America and East Asia. J. Geophys. Res. Atmos., 129, 5001-5019, https://doi.org/10.1029/2017 JD028246.

—, A. Boone, and T. Yao, 2019: Remote effects of high elevation land surface temperature on S2S precipitation prediction: First Workshop on LS4P and TPEMIP. GEWEX News, Vol. 29, No. 1, International GEWEX Project Office, Washington, D.C., in press.

Yan, L., and X. Liu, 2014: Has climatic warming over the Tibetan Plateau paused or continued in recent years? J. Earth Ocean Atmos. Sci., 1 (1), 13-28.
Yang, K., B. S. Ye, D. G. Zhou, B. Wu, T. Foken, J. Qin, and Z. Zhou, 2011: Response of hydrological cycle to recent climate changes in the Tibetan Plateau. Climatic Change, 109, 517-534, https://doi.org/10.1007 /s10584-011-0099-4.

—, H. Wu, J. Qin, C. Lin, W. Tang, and Y. Chen, 2014: Recent climate changes over the Tibetan Plateau and their impacts on energy and water cycle: A review. Global Planet. Change, 112, 79-91, https://doi .org/10.1016/j.gloplacha.2013.12.001.

Yang, X., T. Yao, D. Joswiak, and P. Yao, 2014: Integration of Tibetan Plateau ice core temperature records and the influence of atmospheric circulation on isotopic signals in the past century. Quat. Res., 81, 520-530, https://doi.org/10.1016/j.yqres.2014.01.006.

Yang, Y., and R. C. Ren, 2017: On the contrasting decadal changes of diurnal surface temperature range between the Tibetan Plateau and southeastern China during the 1980s-2000s. Adv. Atmos. Sci., 34, 181-198, https://doi.org/10.1007/s00376-016-6077-z.

Yao, T. D., and L. G. Thompson, 1992: Trends and features of climatic changes in the past 5000 years recorded by the Dunde ice core. Ann. Glaciol., 16, 21-24.

_- and Y. Xue, 2016: Workshop on Land Surface Multi-Sphere Processes of the Tibetan Plateau and Assessment of Their Environmental and Climate Effects. GEWEX News, Vol. 26, No. 4, International GEWEX Project Office, Silver Spring, MD, 24-26.

—, K. Q. Jiao, L. D. Tian, Z. H. Yang, W. L. Shi, and L. G. Thompson, 1996a: Climatic variations since the Little Ice Age recorded in the Guliya Ice Core. Sci. China, 39D, 587-596.

—, L. G. Thompson, E. Mosley-Thompson, Z. Yang, X. Zhang, and P.-N. Lin, 1996b: Climatological significance of $\delta^{18} \mathrm{O}$ in north Tibetan ice cores. J. Geophys. Res., 101, 29531-29537, https://doi.org/10.1029/96JD02683.

— , V. Masson, J. Jouzel, M. Stievenard, S. Weizhen, and J. Keqin, 1999: Relationships between $\delta^{18} \mathrm{O}$ in precipitation and surface air temperature in the Urumqi River Basin, east Tianshan Mountains, China. Geophys. Res. Lett., 26, 3473-3476, https:// doi.org/10.1029/1999GL006061.

— cords over the last $2 \mathrm{ka}$ in Dasuopu ice core. Sci. China, 45D, 1068-1074, https://doi.org/10.1360/02yd9104.

- K. Duan, L. G. Thompson, N. Wang, L. Tian, B. Xu, Y. Wang, and W. Yu, 2007: Temperature variations over the past millennium on the Tibetan Plateau revealed by four ice cores. Ann. Glaciol., 46, 362-365, https://doi.org/10.3189/172756407782871305.

— , and Coauthors, 2012a: Third Pole Environment (TPE). Environ. Dev., 3, 52-64, https://doi .org/10.1016/j.envdev.2012.04.002. 
_ , and Coauthors, 2012b: Different glacier status with atmospheric circulations in Tibetan Plateau and surroundings. Nat. Climate Change, 2, 663-667, https:// doi.org/10.1038/nclimate1580.

—_, and Coauthors, 2015: Multispherical interactions and their effects on the Tibetan Plateau's earth system: A review of the recent researches. Natl. Sci. Rev., 2, 468-488, https://doi.org/10.1093/nsr/nwv070.

Yao, X. J., S. Y. Liu, M. P. Sun, and X. J. Zhang, 2014: Study on the glacial lake outburst flood events in Tibet since the 20th century. Ziran Ziyuan Xuebao, 29, 1377-1390, https://doi.org/10.11849/zrzyxb .2014.08.010.

You, Q. L., S. C. Kang, E. Aguilar, and Y. Yan, 2008: Changes in daily climate extremes in the eastern and central Tibetan Plateau during 1961-2005. J. Geophys. Res., 113, D07101, https://doi.org/10.1029/2007JD009389.

— , J. Z. Min, Y. Jiao, M. Sillanpää, and S. Kang, 2016: Observed trend of diurnal temperature range in the Tibetan Plateau in recent decades. Int. J. Climatol., 36, 2633-2643, https://doi.org/10.1002/joc.4517.

Zeng, Y. J., Z. B. Su, R. van der Velde, L. Wang, K. Xu, X. Wang, and J. Wen, 2016: Blending satellite observed, model simulated, and in situ measured soil moisture over Tibetan Plateau. Remote Sens., 8, 268, https:// doi.org/10.3390/rs8030268.

Zhang, G. S., S. C. Kang, L. Cuo, and B. Qu, 2016: Modeling hydrological process in a glacier basin on the central Tibetan Plateau with a distributed hydrology soil vegetation model. J. Geophys. Res. Atmos., 121, 9521-9539, https://doi.org/10.1002/2016JD025434.

Zhang, R., and Coauthors, 2015: Quantifying sources, transport, deposition, and radiative forcing of black carbon over the Himalayas and Tibetan Plateau. Atmos. Chem. Phys., 15, 6205-6223, https://doi.org/10 .5194/acp-15-6205-2015.

Zhang, R. H., and S. Zhou, 2009: Air temperature changes over the Tibetan Plateau and other regions in the same latitudes and the role of ozone depletion. Acta Meteor. Sin., 23, 290-299.

Zhang, Q. B., G. D. Cheng, T. D. Yao, X. Kang, and J. Huang, 2003: A 2,326-year tree-ring record of climate variability on the northeastern QinghaiTibetan Plateau. Geophys. Res. Lett., 30, 1739, https:// doi.org/10.1029/2003GL017425.

Zhang, X. Q., L. L. Peng, D. Zheng, and J. Tao, 2008: Cloudiness variations over the Qinghai-Tibet Plateau during 1971-2004. J. Geogr. Sci., 18, 142-154, https:// doi.org/10.1007/s11442-008-0142-1.

Zhang, Y. L., and Coauthors, 2015: A 500 year atmospheric dust deposition retrieved from a Mt. Geladaindong ice core in the central Tibetan Plateau. Atmos. Res., 166, 1-9, https://doi.org/10.1016/j.atmosres.2015.06.007.

_, and Coauthors, 2017a: Light-absorbing impurities enhance glacier albedo reduction in the southeastern Tibetan plateau. J. Geophys. Res. Atmos., 122, 6915-6933, https://doi.org/10.1002/2016JD026397.

— , and Coauthors, 2017b: Light-absorbing impurities on Keqikaer Glacier in western Tien Shan: Concentrations and potential impact on albedo reduction. Sci. Cold Arid Reg., 9 (2), 97-111.

Zhao, L., C. L. Ping, D. Q. Yang, G. Cheng, Y. Ding, and S. Liu, 2004: Changes of climate and seasonally frozen ground over the past 30 years in Qinghai-Xizang (Tibetan) Plateau, China. Global Planet. Change, 43, 19-31, https://doi.org/10.1016/j.gloplacha.2004.02.003.

Zhou, S. Q., S. C. Kang, F. Chen, and D. R. Joswiak, 2013: Water balance observations reveal significant subsurface water seepage from Lake Nam Co, south-central Tibetan Plateau. J. Hydrol., 491, 89-99, https://doi.org/10.1016/j.jhydrol.2013.03.030.

Zhou, S. W., and R. Zhang, 2005: Decadal variations of temperature and geopotential height over the Tibetan Plateau and their relations with Tibet ozone depletion. Geophys. Res. Lett., 32, L18705, https:/doi .org/10.1029/2005GL023496.

Zhu, X., W. Wang, and K. Fraedrich, 2013: Future climate in the Tibetan Plateau from a statistical regional climate model. J. Climate, 26, 10 125-10 138, https:// doi.org/10.1175/JCLI-D-13-00187.1.

Zhu, Z. C., and Coauthors, 2016: Greening of the Earth and its drivers. Nat. Climate Change, 6, 791-795, https://doi.org/10.1038/nclimate3004. 